\title{
ENCROACHMENT IN THE EASTERN MEDITERRANEAN BETWEEN THE FOURTH AND THE SEVENTH CENTURY AD
}

\begin{abstract}
Encroachment, or the usurpation of public space by secondary structures, is nowadays often considered indicative of economic prosperity. This opinion is largely based on laws and literary sources, whereas many archaeological remains are still categorised as the houses of squatters. This article considers mainly archaeological sources which show the evolution of encroachment throughout Late Antiquity. An overview of its topographical settings within the city and its connection to other buildings is offered, together with an assessment of its appearance and function. These elements are then used to establish the degree of public involvement in its construction and to explain the chronological and topographical spread of encroachment.
\end{abstract}

\section{INTRODUCTION}

The term 'encroachment' is used to indicate the usurpation and subdivision of public space by smaller structures. Encroachment is found both in colonnaded streets and in narrow alleys, on public squares, inside and adjoining public buildings and monuments. Whereas the occurrence of such secondary structures has long been considered indicative of the degeneration of the Roman city under Arab rule, it did in fact already appear in the fourth century AD, all over the Roman Empire ${ }^{1}$. Today, encroachment is considered typical of the late antique and early Byzantine city, and no longer necessarily indicative of decline, but also of economic growth (Kennedy 1985a, 17, 22-26; Ward-Perkins 1998, 382). This article will assess the occurrence of encroachment in the Eastern Mediterranean between the fourth and the seventh century AD by reviewing the archaeological evidence of seven towns, Ephesus, Sardis, Hierapolis, Sagalassos, Antioch-on-the-Orontes, Apamea-on-the-Orontes and Gerasa. An attempt will be made to compare the appearance and acceleration of

\footnotetext{
1 Original reception, see SAuvaget 1934, 100, fig. 8. Both Ellis 1988, 566-567 and SARADI 1998, 17-18 stressed the early moment of its appearance. For encroachment in general, see recently SARADI 2006, especially 186-207 containing an overview of literary sources. For examples from the West-Roman Empire, see KEAY 1996, 36; LoSEBY 1996, 52-54; Roskams 1996, 259; for North-Africa, see Potter 1995; WILSON 2001; LeONE $2003,274-282$.
} 
the phenomenon in these cities, to describe it in terms of form, measurements and materials used, to establish its overall development in terms of dating and location, to establish the diverse public and private functions of smaller structures encroaching on public space and to connect their presence with changes in the late antique and early Byzantine society.

An all-comprising study of encroachment faces several difficulties. First of all, the nature of the structures themselves causes problems. Due to their manner and quality of construction, their preservation is often fragmentary. Dating is difficult or even impossible due to the lack of datable material, for instance when the new occupants used the existing street pavement or the original floor as foundation for new walls. For structures in wood or other perishable materials, even attesting their presence is problematic (cf. infra). Secondly, as so many other postRoman remains, encroachment-structures suffered severely from deficient excavation techniques and from the excavators' wish to expose the attractive classical city and make it accessible for tourism. Walls made of rubble or an amalgam of building materials are unattractive to both sponsors and tourists, whereas the search for postholes and earthen walking levels is time-consuming and expensive. In the past (and present?) this has led to speedy excavations and the removal of minor structures. As a consequence, especially in towns where excavations were started a long time ago, a large part of the encroachment has disappeared without leaving any record.

\section{ENCROACHMENT THROUGH TIME}

In the following section, an evolutionary sketch of encroachment encountered in the seven case-studies is provided ${ }^{2}$. For reasons of convenience, the long period under research was by means of a trial-and-error-process divided into four phases, which group instances of encroachment of similar nature. The first phase ends around $\mathrm{AD} 300$, the traditional date for the beginning of Late Antiquity; the second ranges from $\mathrm{AD} 300$ to

\footnotetext{
2 Though many more examples were originally collected and discussed, for the purpose of this article a selection has been made. Figures 1, 4-6 and 9-10 used in the text are copyrighted by the Sagalassos Project; Figures 2 and 11 courtesy of the American Schools of Oriental Research; Figure 3 courtesy of the Austrian Academy of Sciences; Figures 8 and 9 , photos by the author.
} 
450/75; the third ends in $\mathrm{AD} 550 / 75$. The final phase comprises the second half of the sixth century, the years that are considered to have been decisive in the decline of the Roman Empire, and ends between the late sixth, early seventh century and AD 635/50, when the Semitic provinces of the Near East and Asia Minor were invaded by the Persians and a few decades later by the Arabs, and cities as Sagalassos and Hierapolis were severely damaged by natural phenomena.

\section{Encroachment before AD 300}

The oldest instances of encroachment attested today were not located on larger public spaces, but in smaller streets. Already in the first century, the owner of Terrace House 2, Unit 1 at Ephesus incorporated a small section of the narrow alley in between both Terrace Houses. This example was followed by the owners of other units (Wiplinger 2002, 69-76; Thür 2002, 47-59, 61). All streets, both large and small, were public spaces guarded from private interventions by imperial legislation $(C J$ VIII, 11, 20 [AD 439]; Saradi 2006, 204-206). Nevertheless, the public character of a monumental colonnaded street is far more evident than that of a narrow and stepped alley only used by a limited public.

By AD 300, also some monuments in Ephesus and Gerasa had already been usurped for other activities than those originally intended. After the roof of the Celsus Library had collapsed during an earthquake in AD 262, a civilian incorporated the monument into his house (Alzinger 1971, 1632; Hueber en Strocka 1975, 5; Foss 1979, 65). When the south-western part of the hippodrome at Gerasa collapsed in the second half of the third century AD and horse races could no longer be held, its northern part was converted into an arena, whereas in the south an industrial centre was established. The new inhabitants adjusted the substructures of the building to their needs by introducing new, sloppy walls incorporating spolia from the hippodrome, installing ceilings and laying stone or brick floors (Müller 1938, 90-92; Ostrasz 1989, 55; Ostrasz 1991, 240; De Vries and Bikai 1993, 499; Bikai en Kooring 1995, 525-526; Kehrberg and Ostrasz 1997, 169-170).

In this period one would not expect public buildings to be converted for private means. The reasons were mainly local and, as at Gerasa, selfexplanatory: when the hippodrome could no longer fulfil its original purpose, the substructure could be given a new function immediately. In Ephesus, public activities between the mid third and the later fourth 
century in general are largely unknown. Nevertheless, in the following period, far more public buildings were converted for new purposes.

\section{Encroachment between 300 and 450/75}

Private usurpations now also appeared on larger streets. At Sagalassos, modest habitations installed on both sides of the Neon Library also extended onto the newly laid mosaic of the portico in front (Figure 1; Waelkens et al. 1995, 59-60; 1997, 120-125). The earliest evidence for encroachment in a city centre is found at Sardis on the plaza located on the crossing of two main streets in sector MMS/N. Underneath the later phases of the southern portico, foundations belonging to a late fourthcentury latrine and several modest structures, presumably shops, were encountered. These constructions were again dismantled when a new portico was installed just after AD 400 (Greenewalt, Ratté and Rautman $1994,4 ; 1995,7)$. When, also around AD 400, the portico and shopping complex along the Marble Road were rebuilt, a side entrance to the bath-gymnasium complex was converted into shop E3 (Crawford 1990, 51-52). Presumably the extensions of the shops near the Cathedral complex along the cardo at Gerasa also belong to this period (Figure 2). The seventh-century date originally suggested by the excavators is not convincing: not only was the street already in disrepair at that time (Ball et al. 1986, 331-393), but the coins found within the original shops all belong to the fifth and sixth centuries (Crowfoot 1938, 204). Moreover, the added rooms displayed a sense of order and regularity and did not pass the imaginary line formed by the nymphaeum basin they abutted in the north.

Ephesus was struck by another series of earthquakes between AD 358 and 368. For a few decades, the condition of the Library Square was deplorable: breaks in the water conduit caused the water to run down the Stiegengassen, over the Library Square and towards the Agora. A series of water mills was built, the lowest in front of the Celsus Library (Hueber 1997a, 260-261; 1997b, 269). However, by the late fourth century, Ephesus was again rising from its ashes. The promotion of the Embolos as the new commercial, social and political centre of the city caused the removal of earlier usurpations and a general revalidation of the Library Square (Bauer 1996, 280-282 and Thür 1999, 107, both with further bibliography). The street's commercial function was extended in all directions: in the Embolos itself, the original row of tabernae in front 
of the Terrace Houses was extended with two extra shops that blocked Stiegengasse 1 (Eichler 1961, 69; 1963, 54; Vetters 1977, 18; Ladstätter 2002, 35), in the Ortygia Street to the west, shops were installed on the road surface (Figure 3; Vetters 1979, 126-127), whereas at the other end, in the Domitian Street, shops were given front rooms. In the last street, great attention was paid to a tidy and coherent appearance: a marble façade was applied against the shops on both sides of the street and the southern shops did not extend beyond the new frontage (Vetters 1972-1975, 311-320). Though various dates have been suggested, these extensions probably belonged to the later fourth century ${ }^{3}$. The spaces on the Ortygia Street were far more irregular: both new street fronts were built up out of several sections, and, mainly on the southern side of the street, with varying widths. The spaces in the north were added one by one, the most eastern being the last addition.

Already around $\mathrm{AD} 400$, encroachment was thus very much present in the main streets of Ephesus. Libanius testifies to the presence of private constructions in the colonnaded streets of Antioch in the second half of the fourth century, where they apparently formed an unusual, but welcome addition to the city revenues (Libanius, Orationes XXVI, 20-22). Imperial edicts forbade to erect such structures in Constantinople 4 . Encroachment did not therefore first appear in small provincial towns, while the larger cities retained their regular and orderly appearance for a longer period.

Though public squares in general underwent few changes in this period, the character of the Agora at Hierapolis was drastically altered. It had been severely damaged by an earthquake around AD 350. The town itself was rebuilt, though without the imperial intervention it had enjoyed in the past. Its new, late fourth, early fifth-century fortification wall excluded the Agora, which was subsequently turned into a residential and artisanal quarter, where both lime burning and ceramic production

3 EICHLER $(1961,73)$ dates these changes in the second half of the fourth century, VETters $(1972-1975,321)$ pushed it forward to the post-Justinian period. A date in the late fourth, early fifth century is supported by the following arguments: the wall technique used was applied by the end of the fourth century, the level rise of the street can best be explained as a levelling of earthquake rubble; as there has been little activity attested in this quarter in the second half of the sixth century, an extension of a row of shops is hard to explain.

4 E.g., CTh XV $1.39=$ = CJ VIII 11.14 (398); CTh XV 1.25 (389); CJ VIII 10.12 (reign of Zeno, 474-491); CTh XV $1.46=$ CJ VIII 10.9 (406). CTh XV 1.47 (409) mentions usurpations on the grounds of the imperial palace. 
took place (de Bernardi Ferrero 1984, 436; 1985, 502; 1986, 194; 1987 , 226; 1988, 294; 1989, 246; 1990, 226-227; 1995, 96; Gates 1994, 277; D'Andria 2001, 104-108, 112-113; Whittow 2001, 140-141). This conversion caused further changes to the shops along Frontinus Street, which were no longer used for commercial purposes but turned into houses that also extended onto the square, and to the large latrine along the street, which thereafter functioned as stable, residence and ceramic workshop (de Bernardi Ferrero 1989, 246; 1990, 226-227; 1995, 97; 1996, 87; 1997, 238-239).

In the course of the fourth century, the residential area to the west of the Church of Theodore at Gerasa was developing quickly. Originally, a smaller street connected the Sanctuary of Artemis to the southern decumanus. Already in the third century, it was partially obstructed by the construction of a large cistern and the dumping of the excavated earth on top of the road surface. In the course of the fourth century, the remaining street surface was incorporated into several houses (Fisher 1938a, 281294). By this time, the Sanctuary of Artemis had fallen from use so that the connection to the decumanus lost much of its meaning anyway. The subdivision of another alley to the south of the sanctuary was no doubt brought about by the same reason (Fisher 1938a, 271-272). At Sagalassos, a large urban villa located along the major north-south axis of the town extended onto the street in the early fourth century (Figure 4; Martens 2007, 352; Uytterhoeven and Martens forthcoming). Its annexes were narrow spaces which only took in a minimal part of the road, thus causing little disruption to traffic. They are very similar to the sixth-century extensions of some large residences at Apamea (cf. infra), and can be attributed to the original owners ${ }^{5}$.

In addition to usurpations of public infrastructure, many public buildings were also taken over in this period. The Harbour Gymnasium and the Halls of Verulanus at Ephesus were not reconstructed after the mid fourth-century earthquakes. Instead, a residential area arose, comprising houses of different sizes and gradations of wealth (Alzinger 1971, 16091611; Scherrer 1995, 178; Keil 1964, 76, 80; Foss 1977, 472; 1979, 60). In the early fourth century, Temple $C$ at Gerasa, located amidst a residential area, was turned into a house by subdividing the porticoes of the peristylium (Fisher and Kraeling 1938; Fisher 1938a, 287-289). At the end of the century, the temenos of the Artemis Temple was converted

5 Cf. infra. 
into a building yard, where temple spolia were reworked before being taken to a new destination; occupants moved into the southern portico, which, not coincidentally, was located just north of the cited residential area $^{6}$. Also at the Sanctuary of Zeus, artisanal activity apparently began already in the fourth century (Seigne 1989, 48). Around AD 400, Sagalassos was surrounded by a new fortification wall, incorporating both the Doric Temple and the North West Heroon of the city (Waelkens et al. 2000a, 246; 2000b, 560; Loots, Waelkens and Depuydt 2000, 619-626). Subsequently, two smaller structures for water supply were installed against the Heroon (Martens 2001, 69, nota 103; Waelkens et al. 2000b, 561). The poorly-preserved structure in front of the monument may have had a guard function as it was situated just behind the new city gate (Waelkens et al. 1997, 187-188; 2000b, 561). Finally, on the temenos of the city's temple devoted to Hadrian and Antoninus Pius, smaller structures were built (Waelkens et al. 2005, 427-428).

With the exception of temples, most public buildings were still in use by the mid fifth century, even though the city had problems maintaining them due to its financial situation and the first subdivisions would already appear. At the Halls of Verulanus at Ephesus and the Agora at Hierapolis the decision not to rebuild must have been taken at a higher level. A provincial capital as Ephesus was large enough to attract imperial attention, for instance visible in the construction of the Baths of Constantius, but here too reconstruction was slow. It is possible that in both cases ideological motives and an altered vision on pagan cults and sporting culture played a part. As both cities were bishop's sees and all fourth-century emperors, with one exception, were Christians, investment in complexes associated with the old pagan tradition are not to be expected. Finally, the location of the Halls in the centre of the city, between the Harbour and the Tetragonos Agora, may have been decisive in their re-designation.

The growing influence of Christianity certainly played a role in the decay of buildings of the traditional cult, so that space again became available in the centre of the cities. Most temple conversions - for private use, not for ecclesiastical purposes - can be placed in the 150 years after Constantine.

6 Artisanal activities, see BIKAI and Egan 1997, 522; Pierobon 1983-1984, 91-92; SEIGNE 2002, 205-213; encroachment in portico, FISHER and MCCown 1929-1930, 22. 


\section{Encroachment between $A D$ 450/75 en 550/75}

The encroachment in main streets accelerated in this period. The function of the new constructions can however only rarely be identified with certainty. In the columnar hall between the Tetragonos Agora and the Marble Street at Ephesus, a peristyle courtyard, private or public, was established. The northern section of this hall had already been converted into a separate space by blocking the intercolumnia of the Marble Street and separating it from the main hall, after which it had been lavishly decorated (Wilberg and Keil 1923, 82; Foss 1979, 63; Vetters 1987, 81; Scherrer 1995,144$)$. As the columnar hall was used to display law texts and acclamatory inscriptions up to the seventh century, it had clearly not lost its importance (Whittow 2001, 47). The appearance of the colonnaded street to the south of the State Agora changed more drastically when smaller constructions appeared both inside the colonnades and, probably in the following phase, also on the road surface itself (Eichler 1963, 57-59; 1965, 97; 1966, 8-9; Foss 1979, 78-79). Likewise, underneath the portico of the spacious colonnaded street running through sector MMS at Sardis, excavators encountered only one small early sixthcentury structure made of dry rubble, but also many single strata interrupted by pits or spots of plaster and mortar (Greenewalt, Ratté and Rautman 1994, 12; 1995, 6-7). The first have been identified as cooking installations, the last as remains of individual floors.

In Sagalassos also, encroachment accelerated, most likely after an earthquake in the early sixth century. At two locations, the street was made narrower, while elsewhere small structures with an unknown function were erected (Martens 2007, 347-351). In this period, many of the town's market places were partly or completely usurped. For instance, the western portico of the Upper Agora was converted into shops and workshops, probably in the second half of the fifth century (Figures 5 and 6; Waelkens et al. 2002, 12; 2006, 236-237). Some years before, a church had been constructed inside the courtyard of the former Bouleuterion on the terrace just above the portico. In the early sixth century, the portico area was reorganised; it was now dominated by a monumental flight of steps leading up from the Agora to the atrium of the Church. To the south of this staircase the portico was again subdivided into several small rooms; to the north, the fifth-century workshops were dismantled (Waelkens et al. 2002, 12). Also in the early sixth century, the porticoes along the Lower Agora were replaced by commercial structures: in the 
west food was prepared and sold in a row of small individual shops (Figure 7; Waelkens et al. 2000a, 368); to the northeast of the Agora, three singular rooms with unknown functions were installed, whereas, at the same time, the eastern portico was replaced by a larger thermopolion, a restaurant for serving hot meals and drinks (Figure 8; Waelkens et al. 2006, 229; Putzeys 2007, 262-273). On the State Agora of Ephesus, probably at the end of the fifth or in the first half of the sixth century at the latest, one and probably two cisterns were installed (Eichler 1965, 96-97). In the sixth century, the same happened in the entrance portico of the Agora at Apamea (Aurenche 1983, 297). This suggests a more problematic water provision, and difficulties in maintaining the aqueducts.

Private usurpation of secondary streets also became more widespread. In early sixth-century Apamea, utilitarian spaces belonging to private mansions were installed on the edges of smaller streets ${ }^{7}$. Conversely, the Atrium Church completely blocked a cardo, making all traffic impossible and initiating further private encroachment. In the same phase, the shops along the decumanus in the north were eliminated by the Church's new side aisle and enlarged atrium (Napoleone-Lemaire and Balty 1969, 13-14, 27, 69-70, 75, 83-84). The Terrace Building to the north of the Upper Agora at Sagalassos was, in the early sixth century, subdivided into workshops and shops, while extra shops were attached both to the east and west of the main building (Waelkens et al. 1997, 168-173; 2000a, 273-292). The conversion of the area to the north of the State Agora at Ephesus started already somewhat before AD 500: the temple of Augustus and Artemis was taken over by the residential area on the slopes of the Panayırdağ, inside the prytaneion a cistern was installed and inside the eastern end of the basilica a prosperous civilian constructed a comfortable house with peristylium ${ }^{8}$. The encroachment in and near older temples thus continued, though on sites that had mostly already been converted in the earlier period: at Sagalassos at the end of

\footnotetext{
7 La Maison aux consoles, BALTy 1984a, 19-36; 1989, 90; La Maison aux pilastres, Gisler and Huwiler 1984, 90-92; BALTy 1984b, 496-497; Foss 1997, 219; La Maison au triclinos, BALTY 1984a, 15, fig. 5.

${ }^{8}$ For the residential area on the Temple of Artemis and Augustus, see EICHLER 1961, 68; AlzINGER 1972-1975, 295-299; Foss 1979, 80; 1977, 473; VETTERS 1972, 3, fig. 1; for the conversion of the prytaneion, EICHLER 1961, 68; AlZINGER 1971, 1647; 1972 1975, 248-249; for the house established in the basilica, EICHLER 1968, 80-82; AlzINGER 1972-1975, 299; BAUER 1996, 291 and for structures found on the Agora itself, EICHLER 1965, 96-97; VetTers 1972, 3, fig. 1.
} 
the fifth century a second structure was built against the Heroon, again possibly intended to guard the city gate. In the early sixth century, the second encroachment phase near the temple of Hadrian and Antoninus Pius commenced. Inside the cryptoporticus of the lower terrace of the Temple of Zeus at Gerasa several small rooms with mosaic floors, installed by the end of the fifth century, were attributed to a monastic community (Rasson en Seigne 1989, 119-121).

The final conversion of the civic centre around the State Agora at Ephesus, the growing encroachment on streets, piazzas and inside public buildings and the apparent neglect of the street in sector MMS at Sardis, indicate a changed mentality towards the traditional city in the late fifth and the sixth century. However, at Sagalassos for instance, the large number of reconstructions and renovations initiated in the early sixth century suggests that a form of directing leadership was still present (Waelkens et al. 2006, 229-231). Most importantly, contrary to the following period, in all cities economic activities apparently continued uninterrupted.

\section{Encroachment between $A D$ 550/75 and 635/50}

After the mid sixth century, encroachment reflecting economic transactions was still to be found at some locations. For instance, in the entrance portico of the Baths of Placcus at Gerasa presumably two shops were installed (Fisher 1938a, 265-269). Commercial activity continued in the porticoes of the Marble Road at Sardis. The shops extended into the portico by means of permanent structures in stone, whereas find distribution revealed that at the time the shops were destroyed, goods were also displayed on trestles of perishable materials (Figure 9; Crawford 1990, 37-38, 44). However, at the same time, many of the shops originally connected with dye production seem to have gone out of use and were converted into dwellings (Harris 2004, 112-114). In the same period, the colonnaded street at sector MMS was dilapidated and covered with dumped debris (Greenewalt, Ratté and Rautman 1995, 7). Also at Sagalassos, debris and refuse were no longer evacuated but discarded inside the city centre itself (Waelkens et al. 2006, 231-233). For the first time encroachment on colonnaded streets also included the road surface. On the Arkadiane at Ephesus, this started just after AD 614-616 at the latest (Keil 1964, 83; Schneider 1999, 467, 475). At Antioch, the first private constructions on the cardo may have appeared not long after its 
Justinianic reconstruction and certainly before the Arab conquests ${ }^{9}$. At Apamea, they may have been erected shortly after the earthquake of $\mathrm{AD}$ 573 (Balty and Balty 1969, 41-42; Balty 1972a, 17-18; Kennedy 1985b, 162-163, note 57; Foss 1997, 208).

The extension of residential areas on the alleys between the houses was still continuing. In Hierapolis, the alley next to the House with the Ionic capitals was possibly usurped after AD 550/75 (de Bernardi Ferrero 1990, 228; Whittow 2001, 141). At Antioch, house A extended on the alley in the east (Fisher 1934, 11, fig. 7). At Gerasa, the streets in the residential area to the west of the Church of Theodore were still being adjusted four centuries after the first usurpation. The houses were separated from the Church of Theodore by a continuous wall. The church could thereafter only be reached through a narrow alley, whereas the cut-off road surface in the north was changed into several rooms (Fisher 1938a, 294).

In this period, many inhabited areas became deserted: part of the structures at the Agora of Hierapolis were abandoned in the second half of the sixth century, while the earthquake of the mid seventh century stopped the early Byzantine occupation completely. Also the artisanal quarter at the hippodrome of Gerasa had largely stopped its production by $\mathrm{AD} 600$, whereas both agorae of Sagalassos were apparently abandoned before the town was hit by an earthquake around AD 590. Other complexes underwent a total transformation, completely losing their traditional function. The bath-gymnasiumcomplex at Sardis was, after the destruction of the town during the Persian invasions, used for ceramic production, lime-burning and metal workshops. The northern part of Gerasa was largely abandoned after the mid sixth century. In the shops along the cardo and the northern decumanus, stables were installed (Ball et al. 1986, 357-365). These were again deserted in the early seventh century and only served for the dumping of rubbish. The oval plaza in the south, and possibly even the round plaza at the crossing of the southern decumanus and the cardo, became encroached by several walls, possibly residential structures (Fisher 1938b, 157; Pierrobon 1983-1984,

9 LASsus 1972, 26-27, 66, 84-85, 89-91, 104-106; KENNEDY 1985b, 153-154. Opinions on the date vary: Lassus placed all structures after the Arab conquest, Kennedy dated them to the end of the sixth century, while POTTER $(1995,85)$ thought some of them were Justinianic. The usurpations probably started not long after the reconstruction in AD 540, since, despite the swift rise in street level, many of them were located directly on top of the paving. 
90, 94; Kraeling 1938b, 105, 109, 113-115; Harding 1949, 19). The same happened at the Agora of Apamea (Balty 1972a, 26; Foss 1997, $108,110)$. After the mid sixth century, on top of the rubble of the Terrace Houses and above the old Stiegengasse 1 at Ephesus, a storehouse, cistern and watermills were located (Vetters 1970, 111; 1971, 93-94; 1973, 186-7; Wikander 2000, 388; Wiplinger 2002, 88). In this period the so-called Nymphaeum, one of the honorific monuments along the Embolos, was converted into a metal workshop (Figure 10; Thür 1999, 117-119). By 635/650, life in these cities had thus altered so drastically that it was no longer comparable with that in the centuries before.

\section{TOPOGRAPHICAL SETTINGS AND BUILDING PROPERTIES}

Another major difficulty with encroachment is establishing its nature and function. Ideally, this is achieved based on internal evidence, finds and their distribution ${ }^{10}$. In addition, or when finds are insufficient or non-existent, we can obtain information from the setting of encroachment within the city. Moreover, also the building technique, size and regularity of the structures can contribute to their interpretation.

\section{Settings}

Many constructions in city centres, along busy streets, on top of foral agorae and abutting functioning public buildings, had a commercial function. As is the case today, we can imagine that such building plots were sought after, as all those passing by formed a large potential clientele. Even when the structures themselves have almost disappeared, their context can be useful in determining their function. For instance, though the earliest encroachment structures encountered at Sardis are badly known, it can be assumed that in this prosperous period sites with a commercial-artisanal function were set up at the intersection of two main streets, adjacent to the functioning baths and the newly adorned Synagogue (Seager 1972, 433-434; Hanfmann 1983, 168-174).

Structures with a commercial-artisanal function along main streets and agorae were not a late antique innovation. In the Imperial Age too shopkeepers and artisans displayed their goods outside their shops on

10 See for instance PuTZEYs 2007 for contextual analysis at Sagalassos. 
simple wooden shelves or trestles, as is for instance described by Martial or depicted on Early Imperial reliefs ${ }^{11}$. Such activities took place, for example, at the Theatre Street at Ephesus (Knibbe 1985). In the first third of the third century, the street and its porticoes were restored by $\mathrm{M}$. Fulvius Publicianus Nikephoros. The inscriptions commemorating his endowment suggest that each trade was awarded one to four, and mostly two, intercolumnia. Though the meaning of this phrase is not completely clear, in the last phase of the street ${ }^{12}$, two neighbouring trades marked their boundary by inscribing the names of both professions on the column between them. This was clearly useful in avoiding quarrels over the use of space underneath the porticoes. The third-century inscription might thus refer to an early portico subdivision and even confirm an existing situation. In this particular case, the intensive commercial use of the street is probably connected to the many worshippers passing by on their way to the Sanctuary of Artemis ${ }^{13}$.

In a further phase there must have been wooden constructions, booths that remained in place more permanently and required cuttings in the paving. Eventually such structures became petrified. This is not a sign of economic regression, as the owner intended to use the structure for a longer period. In other words, he trusted that the necessary raw materials or merchandise would remain available for a longer period and that his customers would keep on coming. At the same time, he also assumed that his construction would not be removed by the government.

As the colonnaded street played an important role in economic life (Foss 1979, 96-97; Potter 1995, 88; Walmsley 1996, 144), the encroachment of its porticoes was an extension of the original function. Also the other function of colonnaded streets, as carefully controlled lanes where civic largesse and civic pride were displayed, initially lived on (WardPerkins 1996, 15). This changed only when the road surface itself was re-designated, indicating much more far-reaching changes to civic life.

11 Martial VII 61 and for instance Roman reliefs at Florence, Galleria Uffizi inv. no. 313 and 315 , both dating from the first century $\mathrm{AD}$, depicts sales and the displaying of goods inside a portico.

12 The identification with an Asiarch of the first quarter of the third century can only serve as a terminus post quem. Indeed, the heterogeneous appearance of the street makes it likely the columns with the inscriptions were reused in a later, undated renovation, as was for instance also the case at the Marble Road at Sardis around AD 400 (CRAWFORD 1990, 3-5).

13 The street was indeed part of the processional route. Cf. infra. 
Conversely, sites with a smaller visibility, outside the city centre or somewhat removed from its main thoroughfares, hosted artisanal activities and/or houses. At the Hippodrome at Gerasa and the Agora at Hierapolis ceramics and lime were produced. At Hierapolis, the business of the shops along Frontinus Street must have been drastically cut back when visitors to the Agora no longer appeared, and thus they were converted into dwellings. Structures installed just behind city gates, even though they cannot be distinguished on the basis of findings or architecture, probably often had a communal function, such as inspecting or maybe even taxing visitors and merchants entering the city ${ }^{14}$.

\section{Ground plan and building technique}

The ground plan depended in the first place on the shape of the preexisting space. The tabernae in the Embolos at Ephesus had an irregular ground plan, as they had to be fitted in the space available. Porticoes were easily subdivided by the construction of two perpendicular walls, thus creating spaces with a far more regular appearance than those erected in larger open areas, such as agorae, atria, or on the road surface itself. For example, when the first structures were installed inside the peristylium of Temple $\mathrm{C}$ at Gerasa, all rooms were rectangular. A second phase, installed on top of a thick collapse layer, was far more irregular in plan (Fisher 1938a, 287-9). Most later buildings for which the materials used are known, were rectangular or quasi-rectangular. Normally spaces were rather small, between 6 and $16 \mathrm{~m}^{2}$.

Unsurprisingly, encroachment-structures used a wide variety of materials. Although wooden structures in the late antique city are attested in literary and iconographic sources ${ }^{15}$, they have long remained unnoticed in the archaeological record. Their presence was only attested at a few sites, such as Iol Caesarea in Algeria, Philippi and Corinth in Greece and, in a somewhat different form, in the Theatre Street at Ephesus ${ }^{16}$.

${ }^{14}$ For similar structures behind the Southwest Gate at Sardis, see VAN ZANTEN, Thomas and Hanfmann 1975, 45-47 and behind the North Gate of Abu Mina, see GROSSMANN 1998, 276.

15 E.g., Libanius, Orationes XXVI 20-22; CTh VIII 1.45 (406) on wooden structures in the hippodrome of Constantinople. All sorts of installations are also depicted on the sixth-century Yakto-mosaic.

16 Potter 1995, 32-47 for Iol Caesarea; SÈve and Weber 1986, 580 for Philippi; SCRANTON 1959, 141 for Corinth. KNIBBE 1985, 75 mentions wooden beams to hang curtains in between the columns of the Theatre Street at Ephesus. 
Although they did not necessarily leave permanent marks and it is possible that part of them was completely erased during later reconstructions or reorganisations, it is also very likely that on many sites they are not recognised for what they are. For instance, postholes and grooves related to the presence of stalls on the agorae of Sagalassos have only recently been recognised and mapped, even though they were already excavated some ten years ago (Lavan forthcoming a-b). Amongst the more permanent structures, mortared rubble and levelling brick layers showed a regular variation in the Byzantine shops of Sardis, tabernae I and II along the Embolos and the new rooms in front of the shops along the Domitian Street at Ephesus, but this was rather exceptional. Most structures were built of mortared rubble, diverse reused blocks, and an occasional brick layer. Architectural fragments were often taken from the immediate neighbourhood, as in the case of the Agora of Hierapolis or the shops to the west of the Terrace Building at Sagalassos, which reused the ashlars of the old Bouleuterion wall. Room XVI of this complex constitutes a fine example of a mix of wall techniques within the same room: the southern wall was built of recycled ashlars; the northern consisted of two faces of smaller cut stones with a rubble core, the western of ashlars and rubble.

Though details on wall thicknesses are rarely published, ground plans show they differed considerably, not only between two independent units, but also within the same room. Wall thickness was partly dependent on the materials used. For instance, the walls in the northern agora stoa at Hierapolis were between 0.7 and $1.2 \mathrm{~m}$ thick because of the wide variations in re-used architectural blocks. Conversely, the width of walls made of smaller blocks or rubble could be controlled more easily. Such constructions with a more consistent wall width will be discussed in the following section.

When floors were identified, they consisted of beaten earth, brick, mortar layers or stone paving slabs reused from the former structure. Due to the often fragmentary preservation of encroachment-structures, their further finishing is seldom preserved. In the tabernae along the Embolos at Ephesus, wall paintings were found (Vetters 1977, 18). The public/ private building along the Marble Street possibly had a marble decoration. In the sixth century a painted plaster layer was applied to the back wall of the shops in the western portico of the Lower Agora at Sagalassos (Waelkens et al. 2002, 12, 20; Putzeys 2007, 340-344). The Byzantine Shops at Sardis had plastered walls, and those of E8 and E9 were decorated, in the final phase, with frescoes depicting floral scenes (Harris 2004, 116). 


\section{INTERPRETATION}

\section{How private were these usurpations?}

Some conversions of public space, for instance, large cisterns or reservoirs, can easily be recognised as communal initiatives. The closing up of the columnar hall to the west of the Marble Street at Ephesus can because of its location and lavish decoration also be considered as a public undertaking. In addition, literary sources inform us that public space was commandeered not only by the likes of squatters, but also by well-off civilians, who turned porticoes and monuments into profitable acquisitions by leasing them to middle-class shopkeepers and artisans (Saradi 2006, 187, 194 and especially 204-206). In addition, also for the local government such controlled conversion of public space must have been an attractive manner to supplement civic incomes. In the following paragraphs, a subdivision will be made between structures that can truly be ascribed to squatters and those that may have resulted from actions of, or at least were approved by, the authorities. Therefore, we need to assess the general organisation, scale and cohesion of the construction activities. In a first step a division is made between individual structures and those that were part of a larger complex. Especially in the last case, the involvement of a wealthy individual or authority can be assumed. These larger complexes can then be subdivided into those defined as multi-roomed habitation or residential area, and those with another function.

Individual structures. Most encroachment between AD 300 and 550/75 in fact consisted of larger structures or larger complexes. Individual spaces could be found in the porticoed street in sector MMS at Sardis or on the atria of the churches in Gerasa. In a few cases, as for example the structures around the Heroon at Sagalassos, they may be identified as communal initiatives. Only after AD 550/75 did the number of smaller, private structures increase.

Larger complexes with a residential function. In this category, one can be quasi certain that these were constructed by individuals. Also some of these private usurpations could have hardly happened without the consent of the government. For instance, at Ephesus, the development of the residential quarter on the location of the former Halls of Verulanus and Harbour Gymnasium was in fact the redirection of a city quarter, carried out under the eye of the governor and the bishop. The 
establishment of the monastic community in the Temple of Zeus at Gerasa as well is likely to have acquired the permission of the government, to which the bishop also belonged. Then there were also some rather luxurious multiple-roomed residences such as that established behind the façade of the Celsus Library, and that in the basilica on the State Agora of Ephesus ${ }^{17}$. The first appeared in a period in which the city was still recovering from calamities, the second was possibly part of the above-mentioned residential area on the slope of the hill to the north of the State Agora. Finally, there were several modest habitations, such as the fourth-century take-over of Temple $\mathrm{C}$ at Gerasa and probably also the spaces in the southern portico of the Artemis Temple, both of which were again part of a larger residential area. Opposed to shops and workshops, all these residential structures were thus positioned in, on top of or near dilapidated and deserted public buildings, which were often situated outside the contemporary city centre.

Larger complexes with a non-residential function. Then, a group of larger encroachment complexes with a non-residential function remains. When a larger building project was simultaneously conceived and implemented, it can be assumed this was in some way reflected in the regularity of its execution. We are therefore looking for regular complexes, built up of rooms with the same orientation, more or less the same width and/ or length and, ideally, respecting the borders of the original space in which they were installed. The Byzantine shops of Sardis, though not real encroachment except for the incorporation of the Baths' vestibule, were a first example. They were a repetition of the former phase and most likely still installed by the government, but as there were now larger quality differences between neighbouring shops, their actual construction may this time have been the work of individuals ${ }^{18}$. A second instance of a controlled or directed usurpation of public space was the extension of the tabernae behind the Alytarchenstoa at Ephesus. The interior dividing wall between the two spaces was erected parallel to the sidewalls of the other tabernae, which makes it likely that we are also here dealing with a larger building programme, comprising the reconstruction of ten older and the establishment of two new commercial spaces.

17 Libanius, Epistulae 1364 for the adaptation of a pagan temple by an aristocrat, PETIT 1955, 209.

18 CRAWFORD 1990, 6. HARRIS (2004, 87-91, 114) sums up all evidence for an overall planning and coordination in the distribution of functions during the last major reconstruction of the shops. 
The addition of front-rooms to a row of shops may also have been controlled undertakings. For instance in the Domitian Street at Ephesus they formed part of a construction programme affecting the entire street. The shops around the Cathedral complex at Gerasa extended in the same organised manner. The rooms established in the western portico of the Upper Agora at Sagalassos were more or less the same size, possessed the same wall masonry and the same wall width (Figures 5 and 6; Putzeys 2007, 340-344). Likewise, the surfaces taken in by the sixth-century shops in the western portico of the Lower Agora hardly differed; the original borders of the portico were respected (Figure 7); and most significantly, the dividing walls between the separate spaces were on average much thinner than those found in other complexes, as if they had always been intended to serve as interior divisions. Finally, the most northern shop diverted water from the Severan Nymphaeum it abutted, again an action for which we can assume permission needed to be obtained (Waelkens et al. 2002, 20).

All these complexes extended the existing commercial function of their setting. This was also the case with the tabernae complex established on the Ortygia Street to the west of the Embolos (Figure 3). Despite its less regular appearance, it appeared in the centre of the city, which at the time was being repaired and renovated, and abutted the newly constructed ornamental portico to the south of the Celsus Library (Vetters 1979, 126-127). So also in this case, approval of the authorities is quasi certain.

Maybe one of the most likely candidates for organised subdivision of public space was the Terrace Building to the north of the Upper Agora at Sagalassos. It no longer fulfilled its initial public function in Late Antiquity, but because of its oblong and narrow shape, finding it a new destination may have been hard. Leasing or selling it to one or several individuals must have been both more lucrative as well as more pleasing for the town's appearance than letting it fall into disrepair. Although part of the building had possibly already been converted in the fifth century (Waelkens et al. 1997, 164-166), when it needed to be patched up after the earthquake of the early sixth century, privatisation also had the extra advantage that the new inhabitants would execute all necessary repairs themselves. Public involvement in the new shopping centre was implied by the passage of the water supply for the Antonine Nymphaeum along the north of the Upper Agora. In addition, the erection of the shops to the west of the main building coincided with the laying of a 
new staircase connecting the street to the Agora below (Figure 6). At the same time, the western side of the Agora was rebuilt so that the encroachment in the west portico was from then on accompanied by the monumental staircase leading up to the Bouleuterion Church.

Finally, it should be noted that, even when public space remained under control of the government or a wealthy individual, most construction activities were executed by the actual occupants. Another, though more expensive, solution would have involved the employment of a more professional building team to subdivide or construct a new shopping centre, but judging by the overall quality of execution, this did not occur often.

\section{Encroachment and Churches}

The concentration of trades behind, and their possible third-century encroachment into the porticoes of the Theatre Street at Ephesus was probably the result of its location on the processional route to the Artemis Sanctuary. Before Late Antiquity, shops and workshops were frequently concentrated around temples, no doubt as they drew many visitors and worshippers (Saradi 2006, 216 note 1160). Within the late antique city, the liveliest locations were of course its churches. As a consequence, the surroundings of churches now became ideal locations for shops and workshops. At Sagalassos, the construction of the Church in the Bouleuterion may have induced the subdivision of the western portico at the Upper Agora. At Gerasa, the shops next to the entrance of the Cathedral were extended, very likely as they with the construction of the church complex became profitable possessions (Brenk, Jäggi and Meier 1995, 211-213). Finally, also the encroachment on the decumanus and the cardo of Apamea was located in the area of churches, the Church with the Atrium, the Rotunda and the Cathedral (Saradi 2006, 214-216, 423424 with more examples) ${ }^{19}$. In such cases, we can even ask ourselves to what extent the Church itself was actively involved in or responsible for the organisation of these activities ${ }^{20}$. Though there does not need to be a direct connection in all instances, it can be said with certainty the new rulers had little interest in removing these structures.

19 SARADI 2006, 214-216 and 423-424 gives more examples.

20 LAVAN 2003, 317-318, 324-325 for activities in and around churches. See also LEONE 2003, 277-278 and MARTORELLI 1999. In addition, there is little or no evidence to support the theory that these shops only sold religious items. 
In addition, usurpation of church atria themselves started after $\mathrm{AD}$ $550 / 75$. One or possibly both of the courtyards of the Cathedral at Apamea was partly claimed (Balty 1972b, 193-194). At Gerasa, secondary structures were attested in the porticoes of the complex consisting of the Church of Cosmas and Damian, the Church of St. John the Baptist and the Church of Georgos, at the Church of Peter and Paul and the Church of Theodore (Figure 11; Crowfoot 1938, 220-254, Kraeling 1938a, plans $33,37,39)$. Though these have often been attributed to invaders, the fact that they invariably respected church entrances may imply otherwise. In all these cases, a more definite answer is hampered by the lack of information on the correct appearance of the new structures and their interior furnishing. Better results have been obtained at Thebes, Greece, where similar small structures connected to its churches could be interpreted as ecclesiastical undertakings. For example, in an apsidial room to the south of Basilica B, a furnace, a column used to hang cooking pots from and a low table were retrieved, suggesting this location was used to prepare meals. Similarly, repairs to the atrium of Basilica $\mathrm{C}$ included the walling up of the southern stoa. The mosaic adorning this new room and an inscription referring to a teacher suggested that it served as a school (Karagiorgou 2001, 186-190). Other subdivisions inside Thebe's basilicas were attributed to a growing insecurity. Indeed, when in unsafe periods people sought protection within the defended area and demands for food supplies and shelter increased rapidly, subdivision of ecclesiastical buildings could have offered a solution (Karagiorgou 2001, 213-214) ${ }^{21}$.

\section{Explaining Encroachment: Pragmatism in Late Antiquity}

Construction on public spaces does not necessarily point towards population increase. For it was a lot easier for private individuals to build on public spaces or to live in disused, but solidly constructed public monuments than to redevelop a site that first had to be cleared of rubble, or in the best case levelled, before construction could start. For example, at Gerasa, a house was first installed inside the peristyle of Temple $\mathrm{C}$ and only afterwards habitations would be built on the open terrain next to it, starting from zero (Fisher 1938a, 283-284). The same pragmatic attitude was visible at the substructures of the hippodrome at Gerasa, which were

21 Joshua the Stylite, Chronicle $\$ 43$ describes how in AD 500/1 the authorities converted the porticoes of Edessa in Southeast Turkey into emergency shelters for refugees (TROMBLEY and WatT 2000, 44). 
so to speak predefined habitations and workshops, not for one or two individuals but for dozens of inhabitants.

The government itself took on a pragmatic attitude towards the phenomenon. Liebeschuetz $(2001,29-30)$ called it a «laissez-faire attitude», but it was more than that. The civic authorities apparently soon discovered that much was to be gained from encroachment structures. Already in the fourth century they were not removed from the street images, but taxed instead ${ }^{22}$. When in the course of Late Antiquity a town's income would diminish more and more and public buildings could no longer be maintained in a proper manner, a creative solution was needed. The lease or sale of a portico or public monument could not only increase diminished budgets, but even relieved authorities completely from the responsibility to maintain them. The growing encroachment can thus no longer be considered merely as a consequence of a weakened civic government that was no longer able to uphold the law. It would be more correct to say that it was no longer willing to do $\mathrm{so}^{23}$.

Finally, the orthogonal street system was respected the longer the less. Pentz $(1992,49)$ said on this: «in the long history of the East, the GraecoRoman town was nothing more than a long digression; when possible the towns re-established their old oriental plan, with larger strictly planned streets, combined with narrow winding alleys». In spite of the coloured choice of words, the message conveyed seems correct. Also the new sixth-century city quarters of Jerusalem or Scythopolis were loosely planned, with winding streets and looser division of building plots (Foerster and Tsafrir 1987-88, 40-42; Tsafrir en Foester 1994, 106-108). This diversion of the Roman way of doing things is the most conspicuous at Gerasa, where the orthogonal street system was forced upon a chaotic city in the second half of the second century AD (Seigne 1992, 338-340). As is apparent from the organically developing residential quarter to the west of the later Church of Theodore, it was never completely successful. In cities with a deeper rooted Greek and Roman tradition, changes to residential areas seemingly progressed in another

${ }^{22}$ Cf. supra.

${ }^{23}$ The failure to remove earthquake debris is a comparable mixture of necessity and conscious choice. As a consequence, even though it was located in the city centre, Stiegengasse 1 at Ephesus remained at least partly buried from the late third century onwards, the Domitian Street rose by almost a metre in the second half of the fourth century (VetTERS 1972-1975, 318-319), as did many streets at Sagalassos in the early sixth, even though throughout the town extensive renovation works were undertaken (MARTENS 2007, 336-337, 348, 351). 
manner: instead of complete reorganisations, we here find more modest extensions onto smaller alleys.

\section{CONCLUSION}

Encroachment is a well-known feature of every late antique city. A simple explanation for its development does not exist. It is not indicative of either decline or economic growth. Each structure or ensemble of structures came into being through a mixture of local factors and general evolutions in the late antique and Early Byzantine Empire, and the first without the presence of the second would have had far less impact. Until the end of the fifth century ${ }^{24}$, instances are known whereby encroachment was removed by authorities implementing the law. But as during Late Antiquity the incomes of the cities were diminishing, large structures such as the Hippodrome at Gerasa could no longer be rebuilt, especially not when construction of more utilitarian constructions such as circuit walls was more pressing. In general, the attitude of civic authorities towards the encroachment phenomenon softened. After it had become clear that all attempts to stop it had little or no effect, one was most likely inclined to allow it, maybe under certain aesthetic or financial conditions. In addition, in order to increase the civic income, the authorities could actively participate by selling both building parts and complete buildings. The Christianisation of the Empire contributed to encroachment as it was the main cause for the abandonment of some traditional building types, commencing with all the pagan sanctuaries, thereby making new building terrains available.

In city centres, free public space must have been attractive because of its commercial possibilities. Favourable locations along streets, on plazas or near churches were converted to shopping centres, executed in stone or perishable materials. The latter in particular may have been far more numerous than we now suspect, but we are slowly learning how to trace them. As commercial and artisanal extensions can indicate economic growth, and for the shop and/or the area an increased number of customers, encroachment not necessarily equals a setback in prosperity. However, in periods of stress, occupation of deserted buildings and construction on unused terrains was an easy way to create additional living space or to obtain a dwelling.

24 Joshua the Stylite, Chronicle $\$ 29$ for Edessa (Trombley and WATt 2000, 26). 
Until AD 550/75, most structures encroaching on public space were extensions of the original function of the area. For instance, owners of private houses built extra rooms on the street; shops extended into the portico. After the mid sixth century, encroachment not only increased at a faster rate, but spaces were also given completely new purposes that seldom complied with their original use and generally pointed to a downfall of civic life. This may have been the result of a general impoverishment of the Empire after the reign of Justinian and of the Plague, but these factors are with the evidence currently available not (yet?) distinguishable from evolutions that had started earlier. Around AD 600, increasing insecurity also started to play a role in a presumable population concentration in city centres and around churches.

Secondary structures installed in public spaces were very heterogeneous. Some adjustments of public space must have been private undertakings; others may still have possessed a more public function. Until the mid sixth century, many instances of encroachment appear to have been part of larger complexes, owned by the government or a private individual. Such larger-conceived and carefully-planned building programmes have been tentatively identified. Although most of these presumptions cannot (yet) be proven, this approach at least diversifies the encroachment-phenomenon. As it is certain that a variety of structures, with diverse functions and varying degrees of wealth and status, was built into or next to public spaces and monuments in the late antique and early Byzantine city, we can no longer continue placing all excavated remains within the same category of 'encroachment'.

\section{ACKNOWLEDGEMENTS}

This article was part of my $\mathrm{PhD}$ research, carried out as a Research Assistant of the Research Foundation - Flanders, under the direction of Prof. M. Waelkens (K.U. Leuven). I wish to thank all colleagues who have read and commented on it, as well as the anonymous referees for their helpful suggestions. Any errors, of course, remain my own.

Katholieke Universiteit Leuven

Postdoctoral Researcher

Research Foundation-Flanders

Department of Archaeology, Art History \& Musicology

Blijde-Inkomststraat 21 - box 3314

B-3000 LEUVEN
Ine JACOBS

ine.jacobs@arts.kuleuven.be 


\section{REFERENCES*}

AlzINGER, W. 1971: art. Ephesos, RE XII, col. 1588-1704.

AlZINGER, W. 1972-1975: Das Regierungsviertel, JÖAI 50B, p. 229-300.

Aurenche, O. 1983: Chronique archéologique, Syria 60, p. 269-333.

Ball, W., Bowsher, J., Kehrberg, I., Walmsley, A. and Watson, P. 1986: The North Decumanus and North Tetrapylon at Jerash: an Archaeological and Architectural Report, in: ZAYADINE, Z. (ed.), Jerash Archaeological Project 1981-1983, Amman, p. 351-411.

Balty, J.Ch. 1972a: Apamée, 1969-1971, in: Balty, J. and Balty, J.Ch. (eds.), Apamée de Syrie. Bilan des recherches archéologiques. Actes du colloque tenu à Bruxelles les 15,17 et 18 Avril 1972 (Fouilles d'Apamée de Syrie. Miscellanea 17), Brussels, p. 15-31.

Balty, J.Ch. 1972b: Le groupe épiscopale d'Apamée, dit "cathédrale de l'est ", Premières recherches, in: BALTY, J. and BALTY, J.Ch. (eds.), Apamée de Syrie. Bilan des recherches archéologiques. Actes du colloque tenu à Bruxelles les 15,17 et 18 Avril 1972 (Fouilles d'Apamée de Syrie. Miscellanea 17), Brussels, p. 187-208.

Balty, J.Ch. 1984a: Introduction, in: BALTy, J. (ed.), Apamée de Syrie. Bilan des recherches archéologiques 1973-1979. Aspects de l'architecture domestique d'Apamée. Actes du colloque tenu à Bruxelles les 29, 30 et 31 mai 1980 (Fouilles d'Apamée de Syrie. Miscellanea 13), Brussels, p. 11-37.

BALTY, J.Ch. 1984b: Notes sur l'habitat romain, byzantin et arabe d'Apamée. Rapport de synthèse, in: Balty, J. (ed.), Apamée de Syrie. Bilan des recherches archéologiques 1973-1979. Aspects de l'architecture domestique d'Apamée. Actes du colloque tenu à Bruxelles les 29, 30 et 31 mai 1980 (Brussels, Fouilles d'Apamée de Syrie. Miscellanea 13), p. 471-501.

BALty, J.Ch. 1989: Apamée au VIe siècle. Témoignages archéologiques de la richesse d'une ville, in: Hommes et richesses dans l'Empire byzantin, 1. IVe-VIIe siècle, Paris, p. 79-96.

BALTY, J. and BALTY, J.Ch. 1969: Le cadre topographique et historique, in: BALty, J. (ed.), Apamée de Syrie. Bilan des recherches archéologiques 1965-1968. Actes du colloque tenu à Bruxelles les 29 et 30 Avril 1969 (Fouilles d'Apamée de Syrie. Miscellanea 6), Brussels, p. 29-51.

BAUER, F.A. 1996: Stadt, Platz und Denkmal in der Spätantike: Untersuchungen zur Ausstattung des öffentlichen Raums in den spätantiken Städte Rom, Konstantinopel und Ephesos, Mainz.

BiKAI, P.M. and Kooring, D. 1995: Archaeology in Jordan, AJA 99, p. 507533.

BiKaI, P.M. and Egan, V. 1997: Archaeology in Jordan, AJA 101, p. 493-535.

BRENK, B., JÄGGI, C. and MEIER, H.-R. 1995: The Buildings under the Cathedral of Gerasa: The Second Interim Report of the Jarash Cathedral Project, Annual of the Department of Antiquities of Jordan 39, p. 211-220.

* Journal abbreviations are those of L'Année Philologique. 
Crawford, J.S. 1990: The Byzantine Shops at Sardis (Archaeological Exploration of Sardis. Monograph 9), Cambridge (Mass.).

Crowfoot, J.W. 1938: The Christian Churches, in: Kraeling, C.H. (ed.), Gerasa. City of the Decapolis, New Haven, p. 171-262.

D'ANDRIA, F. 2001: Hierapolis of Phrygia: its Evolution in Hellenistic and Roman Times, in: PARRISH, D. (ed.), Urbanism in Western Asia Minor. New Studies on Aphrodisias, Ephesos, Hierapolis, Pergamon, Perge and Xanthos, Portsmouth, p. 97-115.

De Bernardi FerRero, D. 1984: Les travaux de la mission archéologique italienne à Hierapolis de Phrygie, Kazı Sonuçları Toplantısı 6, p. 435-440.

DE BERnARd FerReRo, D. 1985: Les travaux de fouilles et de restauration à Hierapolis, Kazı Sonuçları Toplantısı 7, p. 501-507.

De Bernardi Ferrero, D. 1986: Fouilles et restaurations à Hierapolis en 1985, Kazı Sonuçları Toplantısı 8, p. 193-198.

De Bernardi Ferrero, D. 1987: Report on the Activity carried out by the Mission at Hierapolis in 1986, Kazı Sonuçlart Toplantısı 9, p. 225-235.

De Bernardi Ferrero, D. 1988: Fouilles et restaurations à Hierapolis en 1987, Kazı Sonuçları Toplantısı 10, p. 293-300.

De Bernardi Ferrero, D. 1989: Preliminary Report on the 1988 Excavation Campaign, Kazı Sonuçları Toplantısı 11, p. 245-255.

De Bernardi Ferrero, D. 1990: Les travaux à Hierapolis de Phrygie en 1989, Kazı Sonuçları Toplantısı 12, p. 225-233.

De Bernardi FerRero, D. 1995: Excavations and Restorations during 1994 in Hierapolis of Frygia, Kazı Sonuçları Toplantısı 17, p. 95-105.

De Bernardi FerRero, D. 1996: Excavations and Restorations in Hierapolis during 1995, Kazı Sonuçları Toplantısı 18, p. 85-99.

DE BERNARDI FerRero, D. 1997: Report on the Mission's Activity carried out in 1996, Kazı Sonuçları Toplantısı 19, p. 237-248.

DE VRIES, B. and BIKAI, P. 1993: Archaeology in Jordan, AJA 97, p. 457-520.

EICHLER, F. 1961: Die österreichischen Ausgrabungen in Ephesos im Jahre 1960, AAWW 98, p. 65-75.

EICHLER, F. 1963: Die österreichischen Ausgrabungen in Ephesos im Jahre 1962, AAWW 100, p. 45-60.

EICHLER, F. 1965: Die österreichischen Ausgrabungen in Ephesos im Jahre 1964, AAWW 102, p. 93-109.

EICHLER, F. 1966: Die österreichischen Ausgrabungen in Ephesos im Jahre 1965, AAWW 103, p. 7-16.

EICHLER, F. 1968: Die österreichischen Ausgrabungen in Ephesos im Jahre 1967, AAWW 105, p. 79-95.

ELLIS, S.P. 1988: The End of the Roman House, AJA 92, p. 565-579.

FISHER, C.S. 1934: Bath B, House A, and the Roman Villa, in: ELDERKIN, G.W. (ed.), Antioch-on-the-Orontes, I. The Excavations of 1932, Princeton, p. 8-18.

Fisher, C.S. 1938b: Buildings of the Christian Period, in: Kraeling, C.H. (ed.), Gerasa. City of the Decapolis, New Haven, p. 265-294.

Fisher, C.S. 1938c: The "Forum", in: Kraeling, C.H. (ed.), Gerasa. City of the Decapolis, New Haven, p. 153-158. 
Fisher, C.S. and Kraeling, C.H. 1938: Temple C, in: Kraeling, C.H. (ed.), Gerasa. City of the Decapolis, New Haven, p. 139-148.

FisHer, C.S. and Mccown, C.C. 1929-1930: Jerash, Gerasa 1930, AASO 11, p. 1-61.

Foerster, G. and TsafriR, Y. 1987-1988: The Beth Shean Project. Center of Ancient Beth Shean-North, Excavations and Surveys in Israel 6, p. 25-43.

Foss, C. 1977: Archaeology and the "Twenty Cities" of Byzantine Asia, AJA 81, p. 469-486.

Foss, C. 1979: Ephesus after Antiquity. A Late Antique, Byzantine and Turkish City, Cambridge.

Foss, C. 1997: Syria in Transition, A.D. 550-750: an Archaeological Approach, DOP 51, p. 189-269.

Gates, M.H. 1994: Archaeology in Turkey, AJA 98, p. 249-27.

GisleR, J.-R. and Huwiler, M. 1984: La maison aux pilastres, in: BALTY, J. (ed.), Apamée de Syrie. Bilan des recherches archéologiques 1973-1979. Aspects de l'architecture domestique d'Apamée. Actes du colloque tenu à Bruxelles les 29, 30 et 31 mai 1980 (Fouilles d'Apamée de Syrie. Miscellanea 13), Brussels, p. 79-106.

Greenewalt, C.H., Ratté, C. and Rautman, M.L. 1994: The Sardis Campaigns of 1988 and 1989, in: Dever, W.G. (ed.), Preliminary Excavation Reports. Sardis, Paphos, Caesarea Maritima, Shiqmim, Ain Ghazal, AASO 51, p. $1-43$.

Greenewalt, C.H., Ratté, C. and Rautman, M.L. 1995: The Sardis Campaigns of 1990 and 1991, in: Dever, W.G. (ed.), Preliminary Excavation Reports. Sardis, Bir Umm Fawakhir, Tell el-'Umeiri, The Combined Caesarea Expeditions, and Tell Dothan, AASO 52, p. 1-36.

Grossmann, P. 1998: Abû Mînâ, in: Krause, M. (ed.), Ägypten in spätantikchristlicher Zeit. Einführung in die Koptische Kultur (Sprachen und Kulturen des Christlichen Orients 4), Wiesbaden, p. 269-293.

Hanfmann, G.M.A. 1983: Sardis from Prehistoric to Roman Times: Results of the Archaeological Exploration of Sardis, 1958-1975, Cambridge (Mass.).

HARDING, L. 1949: Recent Work on the Jerash Forum, PalEQ 81, p. 12-20.

HARRIS, A. 2004: Shops, Retailing and the Local Economy in the Early Byzantine World: the Example of Sardis, in: DARK, K. (ed.), Secular Buildings and the Archaeology of Everyday Life in the Byzantine Empire, Oxford, p. 82-122.

Hueber, F. 1997a: Ephesos, gebaute Geschichte (Zaberns Bildbände zur Archäologie), Mainz am Rhein,.

HUEBER, F. 1997b: Zur städtebaulichen Entwicklung des hellenistisch-römischen Ephesos. Phylen, Embolos, Olympieion, Horologeion, Statthalterpalast, Auditorium, Parthermonument, Marienkirche, MDAI(I) 47, p. 251-269.

Hueber, F. and Strocka, V.M. 1975: Die Bibliothek der Celsus. Eine Prachtfassade in Ephesos und das Problem ihrer Wiederaufrichtung, $A W$ 6.4, p. 3-14.

Karagiongou, O. 2001: Demetrias and Thebes: Two Thessalian Port Cities in Late Antiquity, in: Lavan, L. (ed.), Recent Research in Late-Antique Urbanism (Journal of Roman Archaeology. Supplementary Series No. 42), Portsmouth, p. 182-216. 
KeAy, S. 1996: Tarraco in Late Antiquity, in: Christie, N. and Loseby, S.T. (eds.), Towns in Transition. Urban Evolution in Late Antiquity and the Early Middle Ages, Brookfield (Vt.), p. 18-44.

KeHrberg, I. and Ostrasz, A.A. 1997: A History of Occupational Changes at the Site of the Hippodrome of Gerasa, in: Studies in the History and Archaeology of Jordan VI, Amman, p. 167-173.

KeIL, J. 1964: Führer durch Ephesos, Vienna.

Kennedy, H. 1985a: From Polis to Madina, P\&P 106, p. 3-27.

KenNedy, H. 1985b: The Last Century of Byzantine Syria: a Reinterpretation, ByzF 10, p. 141-183.

KnibBe, D. 1985: Der Asiarch M. Fulvius Publicianus Nikephoros, die ephesischen Handwerkszünfte und die Stoa des Servilius, JÖAI 56, p. 71-77.

Kraeling, C.H. (ed.), 1938a: Gerasa. City of the Decapolis, New Haven.

KRAELING, C.H. 1938b: The South Tetrapylon, in: Kraeling, C.H. (ed.), Gerasa. City of the Decapolis, New Haven, p. 103-115.

LAdSTÄTter, S. 2002: Die Chronologie des Hanghauses 2, in: Krinzinger, F. (ed.), Das Hanghaus 2 von Ephesos. Studien zu Baugeschichte und Chronologie (Archäologische Forschungen 7), Vienna, p. 9-40.

Lassus, J. 1972: Les portiques d'Antioche (Antioch-on-the-Orontes 5), Princeton.

Lavan, L. 2003: The Political Topography of the Late Antique City: Activity Spaces in Practice, in: Lavan, L. and Bowden, W. (eds.), Theory and Practice in Late-Antique Archaeology (Late Antique Archaeology 1), Leiden-Boston, p. 314-337.

Lavan, L. forthcoming: The Agorai of Sagalassos in Late Antiquity: an Interpretative Study, AS 57.

LeOne, A. 2003: Topographies of Production in North African Cities during the Vandal and Byzantine Periods, in: LAvan, L. and Bowden, W. (eds.), Theory and Practice in Late Antique Archaeology (Late Antique Archaeology 1), Leiden-Boston, p. 257-287.

Liebeschuetz, J.H.W.G. 2001: Decline and Fall of the Roman City, Oxford.

Loots, L., Waelkens, M. and Depuydt, F. 2000: The City Fortifications of Sagalassos from the Hellenistic to the Late Roman Period, in: WAELKENS, M. and Loots, L. (eds.), Sagalassos V. Report on the Survey and Excavation Campaigns of 1996 and 1997 (Acta Archaeologica Lovaniensia Monographiae 11B), Leuven, p. 595-634.

Loseby, S.T. 1996: Arles in Late Antiquity: Gallula Roma Arelas and Urbs Genesii, in: Christie, N. and Loseby, S.T. (eds.), Towns in Transition. Urban Evolution in Late Antiquity and the Early Middle Ages, Brookfield (Vt.), p. 45-70.

Mansel, A.M. 1974: Recent Archaeological Research in Turkey. Perge, AS 24, p. $48-50$.

Martens, F. 2001: Urban Water Management at Sagalassos. Studying Urban Development from an Hydrological Perspective, in: DEMOEN, K. (ed.), The Greek City from Antiquity to the Present. Historical Reality, Philosophical Concept, Literary Representation, Leuven, p. 49-86. 
Martens, F. 2006: The Diachronic Research of Urban Water Management at Sagalassos (SW Turkey), in: WiPLInGer, G. (ed.), Cura Aquarum in Ephesus, 1 (Bulletin Antieke Beschaving. Supplementa 12), Leiden, p. $165-174$.

Martens, F. 2007: Late Antique Urban Streets at Sagalassos, in: Lavan, L. and ZaninI, E. (eds.), Technology in Transition (Late Antique Archaeology 4.1), Leiden, p. 321-366.

MARTORELli, A. 1999: Riflessioni sulle attività produttive nell'età tardoantica ed altomedievale: esiste un artigianato ecclesistico?, RAC 75, p. 571596.

MAZAR, B. 1971: The Excavations in the Old City of Jerusalem: Second Preliminary Report, 1969-1970 Seasons, Jerusalem, p. 11-13.

MellinK, M.J. 1991: Archaeology in Anatolia, AJA 95: p. 123-153.

Müller, E.B. 1938: The Hippodrome, in: Kraeling, C.H. (ed.), Gerasa. City of the Decapolis, New Haven, p. 85-100.

NAPOLEONE-LEMAIRE, J. and BALTY, J.Ch. 1969: L'église à atrium de la grande colonnade (Fouilles d'Apamée de Syrie 1.1), Brussels.

Ostrasz, A.A. 1989: The Hippodrome of Gerasa: a Report on Excavations and Research 1982-1987, Syria 66, p. 51-77.

Ostrasz, A.A. 1991: The Excavation and Restoration of the Hippodrome at Jerash. A Synopsis, Annual of the Department of Antiquities of Jordan 35, p. 237-250.

ParapetTi, R. 2002: Gerasa und das Artemis-Heiligtum, in: Hoffmann, A. and KeRnER, S. (eds.), Gadara-Gerasa und die Dekapolis (Zaberns Bildbände zur Archäologie), Mainz am Rhein, p. 23-35.

Pentz, P. 1992: The Invisible Conquest: the Ontogenesis of Sixth and Seventh Century Syria, Copenhagen.

Petit, P. 1955: Libanius et la vie municipale à Antioche au IVe siècle après J.C. (Paris, Bibliothèque archéologique et historique 62), Paris.

Pierobon, R. 1983-1984: Soundings in the Temple Terrace, 1978-1980, Mesopotamia 18-19, p. 85-111.

PotTer, T.W. 1995: Towns in Late Antiquity: Iol Caesarea and its Context, Oxford.

PutZeYs, T. 2007: Contextual Analysis at Sagalassos. Developing a Methodology for Classical Archaeology, unpublished doctoral dissertation, University of Leuven.

Rasson, A.-M. and Seigne, J. 1989: Une citerne byzantino-ommeyyade sur le sanctuaire de Zeus, Syria 66, p. 117-151.

Roskams, S. 1996: Urban Transition in Early Medieval Britain: the Case of York, in: Christie, N. and Loseby, S.T. (eds.), Towns in Transition. Urban Evolution in Late Antiquity and the Early Middle Ages, Brookfield (Vt.), p. 262-288.

SARADI, H. 1998: Privatization and Sub-division of Urban Properties in the Early Byzantine Centuries: Social and Cultural Implication, BASP 35, p. 17-43.

SARADI, H. 2006: The Byzantine City in the Sixth Century. Literary Images and Historical Reality (Society of Messenian Archaeological Studies), Athens. 
SAuvAGet, J. 1934: Le plan de Laodicée-sur-Mer, BEO 4, p. 81-114.

SCHERRER, P. (ed.), 1995: Ephesos. Der Neue Führer. 100 Jahre österreichische Ausgrabungen 1985-1995, Vienna.

SCHNEIDER, P. 1999: Bauphasen der Arkadiane, in: FrIESINGER, H. and KRINZINGER, F. (eds.), 100 Jahre österreichische Forschungen in Ephesos. Akten des Symposions Wien 1995 (Archäologische Forschungen 1), Vienna, p. 467-478.

SCRANTON, R.L. 1959: Monuments in the Lower Agora and north of the Archaic Temple (Corinth. Results of Excavations 1.3), Princeton.

SEAger, A.R. 1972: The Building History of the Sardis Synagogue, AJA 76, p. 425-435.

SeIGNe, J. 1989: Jérash. Le sanctuaire de Zeus et ses abords, in: Contribution française à l'archéologie Jordanienne, Amman, p. 40-48.

SEIGNE, J. 1992: Jerash romaine et byzantine: développement urbain d'une ville provinciale orientale, in: Studies in de the History and Archaeology of Jordan IV, Amman, p. 331-341.

Seigne, J. 2002: A Sixth Century Water-Powered Sawmill at Jarash, Annual of the Department of Antiquities of Jordan 46, p. 205-213.

SÈve, M. and Weber, P. 1986: Le côté nord du forum de Philippes, BCH 110, p. 531-581.

ThÜR, H. 1999: Die spätantike Bauphase der Kuretenstrasse, in: PILlinger, R., Kresten, O., Krinzinger, F. and Russo, E. (eds.), Efeso paleochristiana e bizantinalFrühchristliches und byzantinisches Ephesos (Archäologische Forschungen 3), Vienna, p. 104-119.

THÜR, H. 2002: Die Bauphasen der Wohneinheit 4 (und 6), in: KRINZINGER, F. (ed.), Das Hanghaus 2 von Ephesos. Studien zu Baugeschichte und Chronologie (Archäologische Forschungen 7), Vienna, p. 41-67.

Trombley, F.R. and WatT, J.H. 2000: The Chronicle of Pseudo-Joshua the Stylite (Translated Texts for Historians 32), Liverpool.

Tsafrir, Y. and Foerster, G. 1994: From Scythopolis to Baysan. Changing Concepts of Urbanism, in: KING, G.R.D. and CAMERon, A. (eds.), The Byzantine and Early Islamic Near East, 2. Land Use and Settlement Patterns (Papers on the Second Workshop on Late Antiquity and Early Islam) (Studies in Late Antiquity and Early Islam 1), Princeton, p. 95-115.

Uytterhoeven, I. and Martens, F. forthcoming: Private Bathing and Water Consumption at Sagalassos (SW-Turkey) and Asia Minor, in: Cura Aquarum in Jordania. 13th International Conference on the History of Water Management and Hydraulic Engineering in the Mediterranean Region Petra/Amman, 31 March-9 April 2007.

Van Zanten, D., Thomas, R.S., and HanFmann, G.M.A. 1975: The City Walls, in: Hanfmann, G.M.A. and WaldBaum, J.C. (eds.), A Survey of Sardis and the Major Monuments outside the City Wall (Archaeological Exploration of Sardis. Report 1), Cambridge (Mass.), p. 35-53.

VetTERS, H. 1970: Ephesos: vorläufiger Grabungsbericht 1969, AAWW 107, p. 105-123. 
VetTeRs, H. 1971: Ephesos: vorläufiger Grabungsbericht 1970, AAWW 108, p. 85-101.

VetTERs, H. 1972: Ephesos. Vorläufiger Grabungsbericht 1971, AAWW 109, p. 3-12.

VetTERS, H. 1973: Ephesos. Vorläufiger Grabungsbericht 1972, AAWW 110, p. 175-194.

VetTERS, H. 1972-1975: Domitianterrasse und Domitiangasse, JÖAI 50B, p. $311-330$.

VetTERS, H. 1977: Zur Baugeschichte der Hanghäuser, in: JoBST, W., Römische Mosaiken aus Ephesos, 1. Die Hanghäuser des Embolos (Forschungen in Ephesos 8.2), Vienna, p. 17-28.

VetTERS, H. 1979: Ephesos. Vorläufiger Grabungsbericht 1978, AAWW 116, p. 123-144.

VeTtERS, H. 1987: Ephesos. Vorläufiger Grabungsbericht für die Jahre 1984 und 1985, $A A W W 123$, p. 75-110.

WaelKens, M. and the Sagalassos team 1995: The 1993 Excavations in the Fountain House-Library Area, in: Waelkens, M. and Poblome, J. (eds.), Sagalassos III. Report on the Fourth Excavation Campaign of 1993 (Acta Archaeologica Lovaniensia Monographiae 7), Leuven, p. 47-89.

WAelKens, M. and the Sagalassos team 1997: The 1994 and 1995 Excavation Seasons at Sagalassos, in: Waelkens, M. and Poblome, J. (eds.), Sagalassos IV. Report on the Survey and Excavation Campaigns of 1994 and 1995 (Acta Archaeologica Lovaniensia Monographiae 9), Leuven, p. 103-216.

WAelKens, M. and the Sagalassos team 2000a: The 1996 and 1997 Excavation Seasons at Sagalassos, in: WaElkens, M. and Loots, L. (eds.), Sagalassos V. Report on the Survey and Excavation Campaigns of 1996 and 1997 (Acta Archaeologica Lovaniensia Monographiae 11/A), Leuven, p. 217398.

Waelkens, M., Vandeput, L., Berns, Ch., Arikan, B, Poblome, J. and Torun, E. 2000b: The Northwest Heroon at Sagalassos, in: WAELKENs, M. and Loots, L. (eds.), Sagalassos V. Report on the Survey and Excavation Campaigns of 1996 and 1997 (Acta Archaeologica Lovaniensia Monographiae 11/B), Leuven, p. 553-593.

WAELKens, M. and the Sagalassos team 2002: The 2000 Excavation and Restoration Season at Sagalassos, Kazı Sonuçları Toplantısı 23, p. 11-28.

WaElkens, M. and the Sagalassos team 2005: Report on the 2003 Excavation and Restoration Campaign at Sagalassos, Kazı Sonuçları Toplantısı 26, p. 421-438.

Waelkens, M., Vanhaverbeke, H., Martens, F., Talloen, P., Poblome, J., Van Thuyne, T. and Putzeys, T. et al. 2006: The Late Antique City in Southwest Anatolia. A Case Study: Sagalassos and its Territory, in: Krause, J.-U. and Witschel, C. (eds.), Die Spätantike Stadt- Niedergang oder Wandel? Aktes des internationalen Kolloquiums in München am 30. and 31. Mai 2003 (Historia Einzelschriften 190), Stuttgart, p. 199255. 
Walmsley, A. 1996: Byzantine Palestine and Arabia: Urban Prosperity in Late Antiquity, in: Christie, N. and Loseby, S.T. (eds.), Towns in Transition. Urban Evolution in Late Antiquity and the Early Middle Ages, Brookfield (Vt.), p. 126-158.

WARD-Perkins, B. 1996: Urban Continuity?, in: Christie, N. and Loseby, S.T. (eds.), Towns in Transition. Urban Evolution in Late Antiquity and the Early Middle Ages, Brookfield (Vt.), p. 4-17.

Ward-Perkins, B. 1998: The Cities, in: CAMERon, A. and Garnsey, P. (eds.), The Cambridge Ancient History XIII. The Late Empire, AD 337-425, Cambridge.

Whiтtow, M. 2001: Recent Research on the Late-Antique City in Asia Minor: the Second Half of the 6th c. Revisited, in: LAVAN, L. (ed.), Recent Research in Late-Antique Urbanism (Journal of Roman Archaeology. Supplementary Series No. 42), Portsmouth.

WIKANDER, Ö. 2000: The Water-Mill, in: WIKANDER, Ö. (ed.), Water Technology (Technology and Change in History 2), Leiden-Boston, p. 371-400.

Wilberg, W. and KeIL, J. 1923: Die Agora (Forschungen in Ephesos 3), Vienna, p. $1-168$.

Wilson, A. 2001: Urban Economies of Late Antique Cyrenaica, in: KINGSLEY, S. and DECKER, M. (eds.), Economy and Exchange in the East Mediterranean during Late Antiquity. Proceedings of a Conference at Somerville College, Oxford, 29 ${ }^{\text {th }}$ May 1999, Oxford, p. 28-42.

WIPLINGER, G. 2002: Die Bauphasen der Wohneinheiten 1 und 2, in: KRINZINGER, F. (ed.), Das Hanghaus 2 von Ephesos. Studien zu Baugeschichte und Chronologie (Archäologische Forschungen 7), Vienna, p. 67-92. 


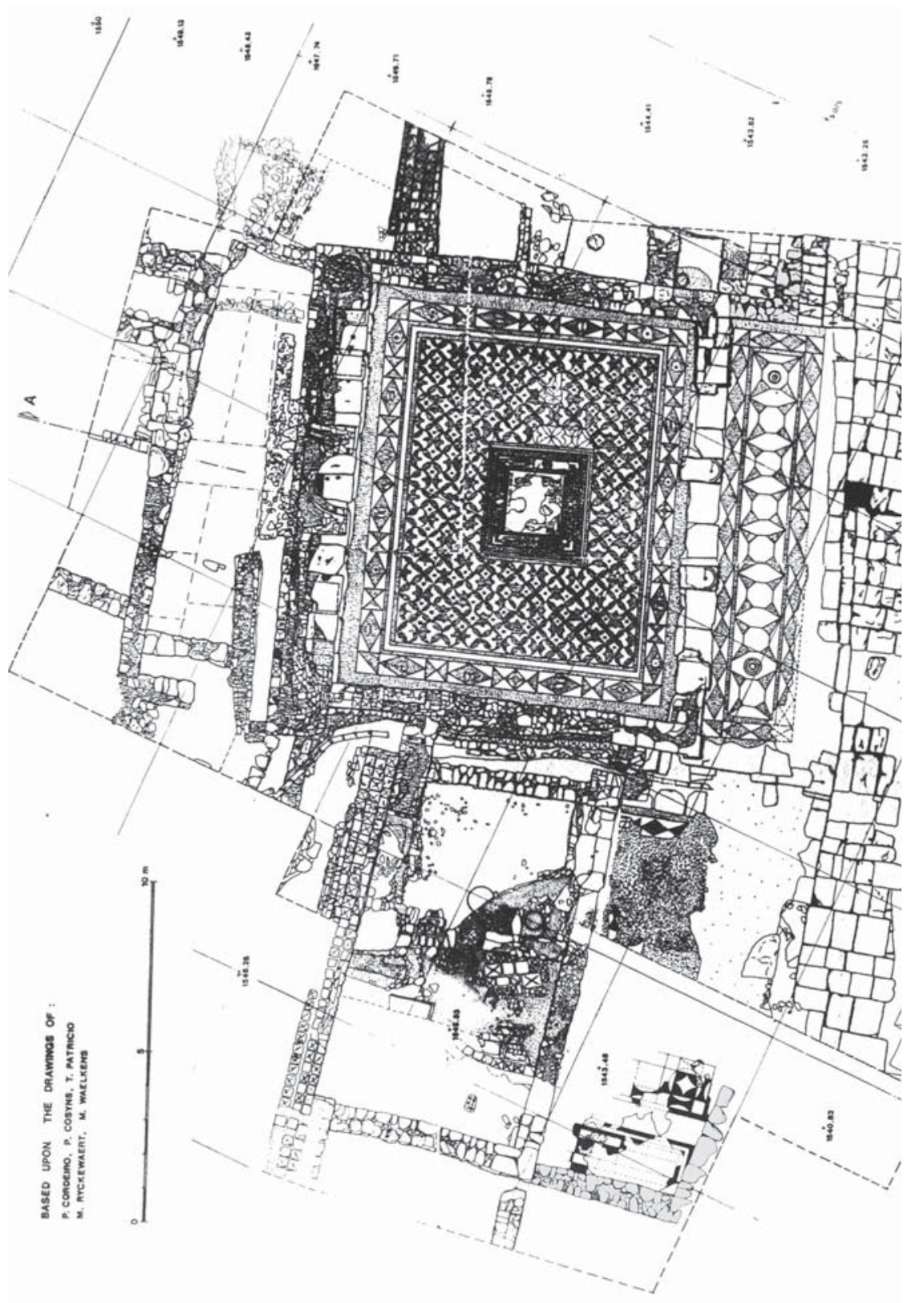

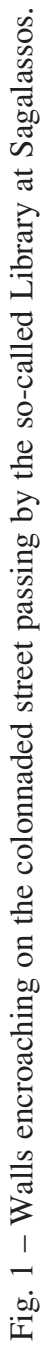




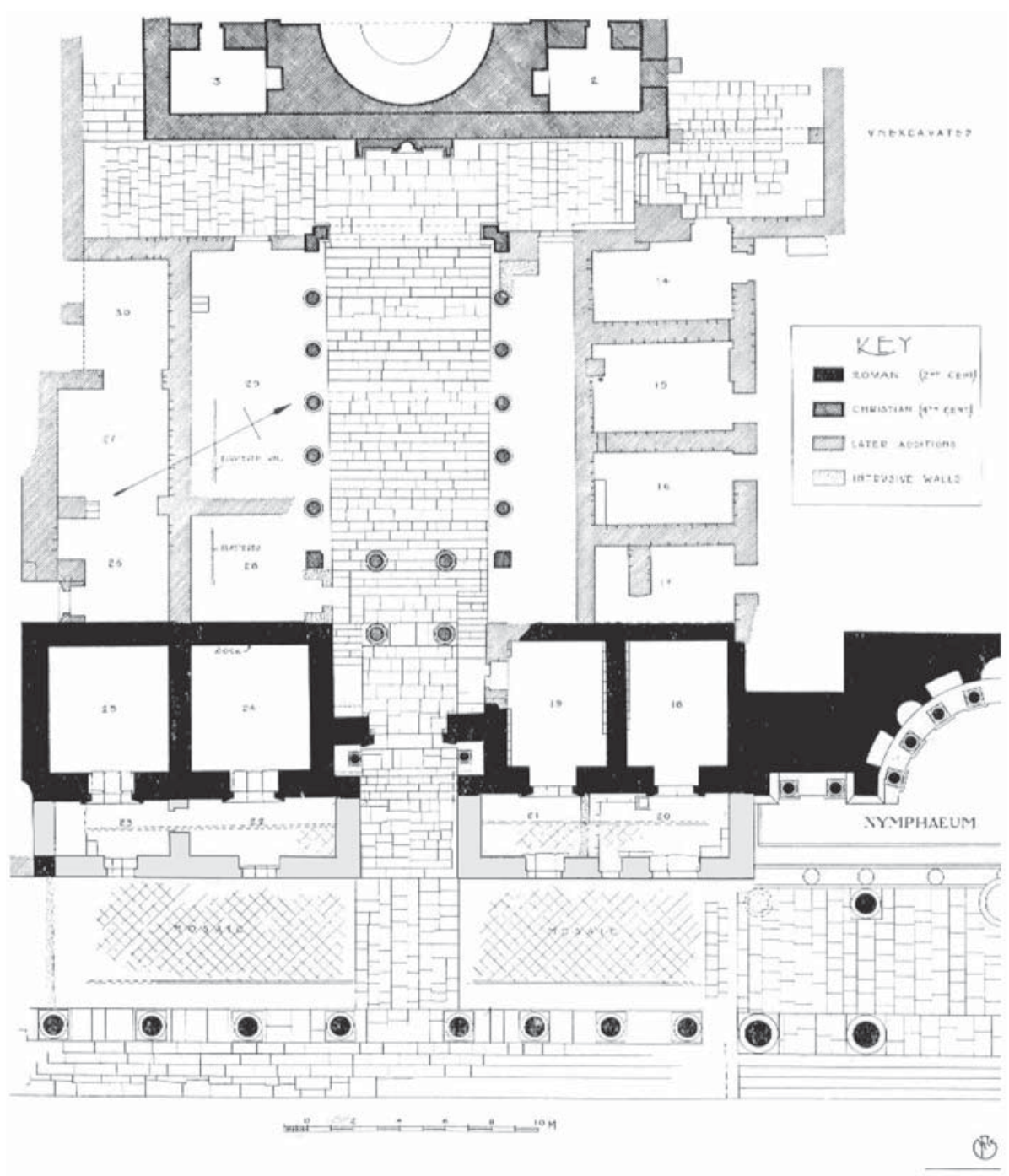

Fig. 2 - The shops on both sides of the staircase leading to the Church of Theodore at Gerasa (adapted from Kraeling 1938, plan 29). 


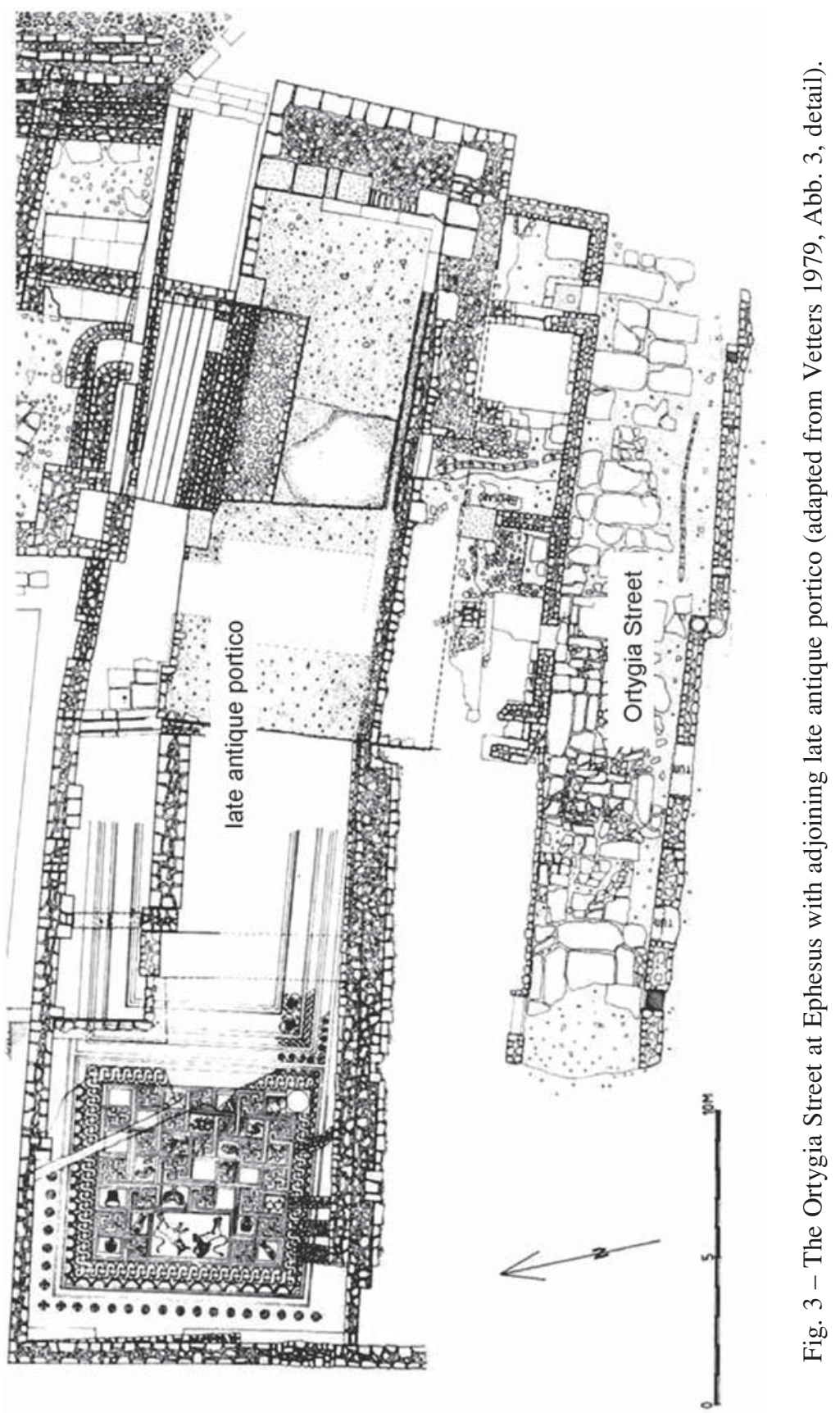




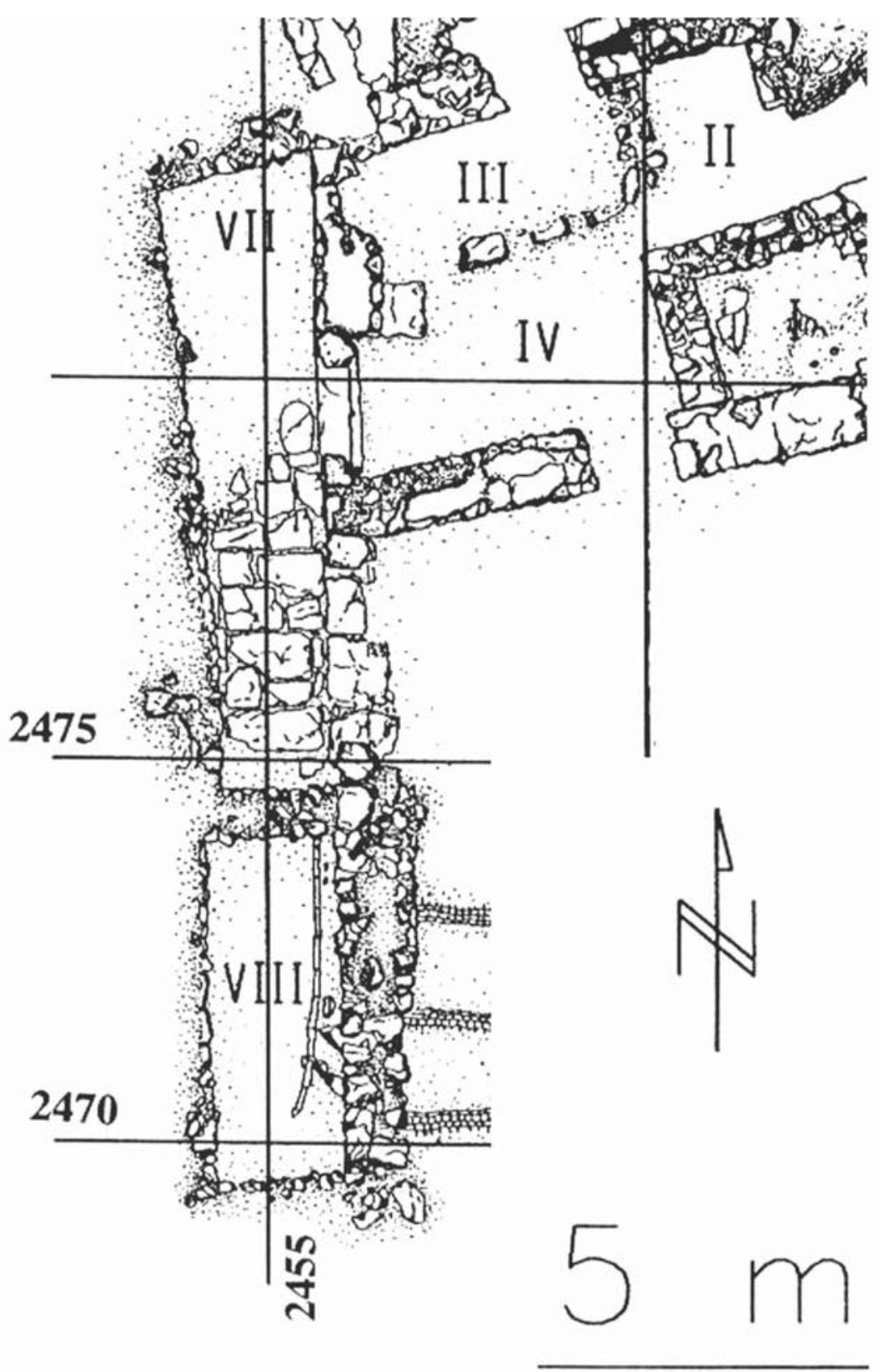

Fig. 4 - Fourth century extensions VII and VIII of a private mansion at Sagalassos. 


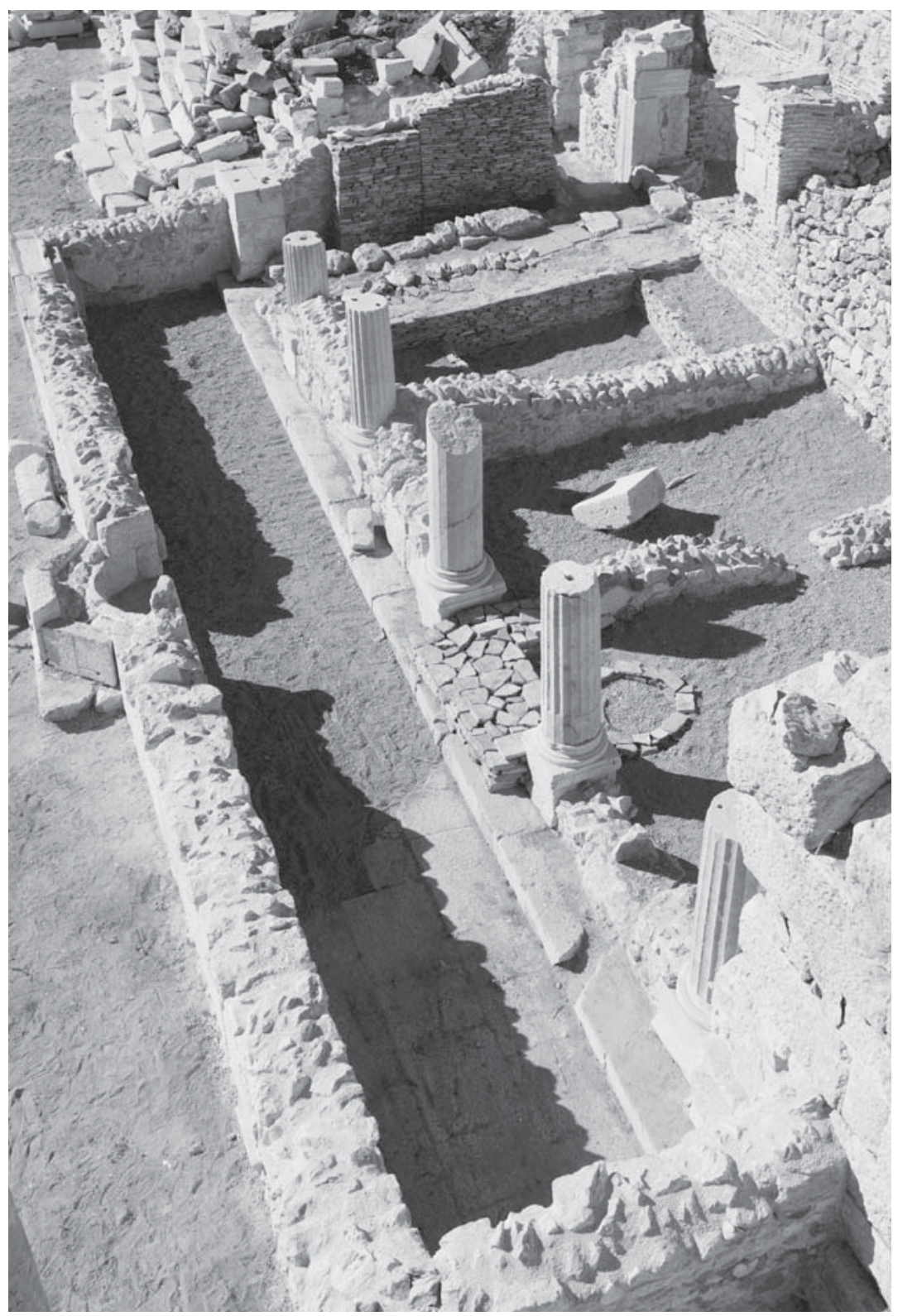

Fig. 5 - The subdivision of the west portico of the Upper Agora at Sagalassos, with the sixth century water basin installed on top of the agora pavement. 


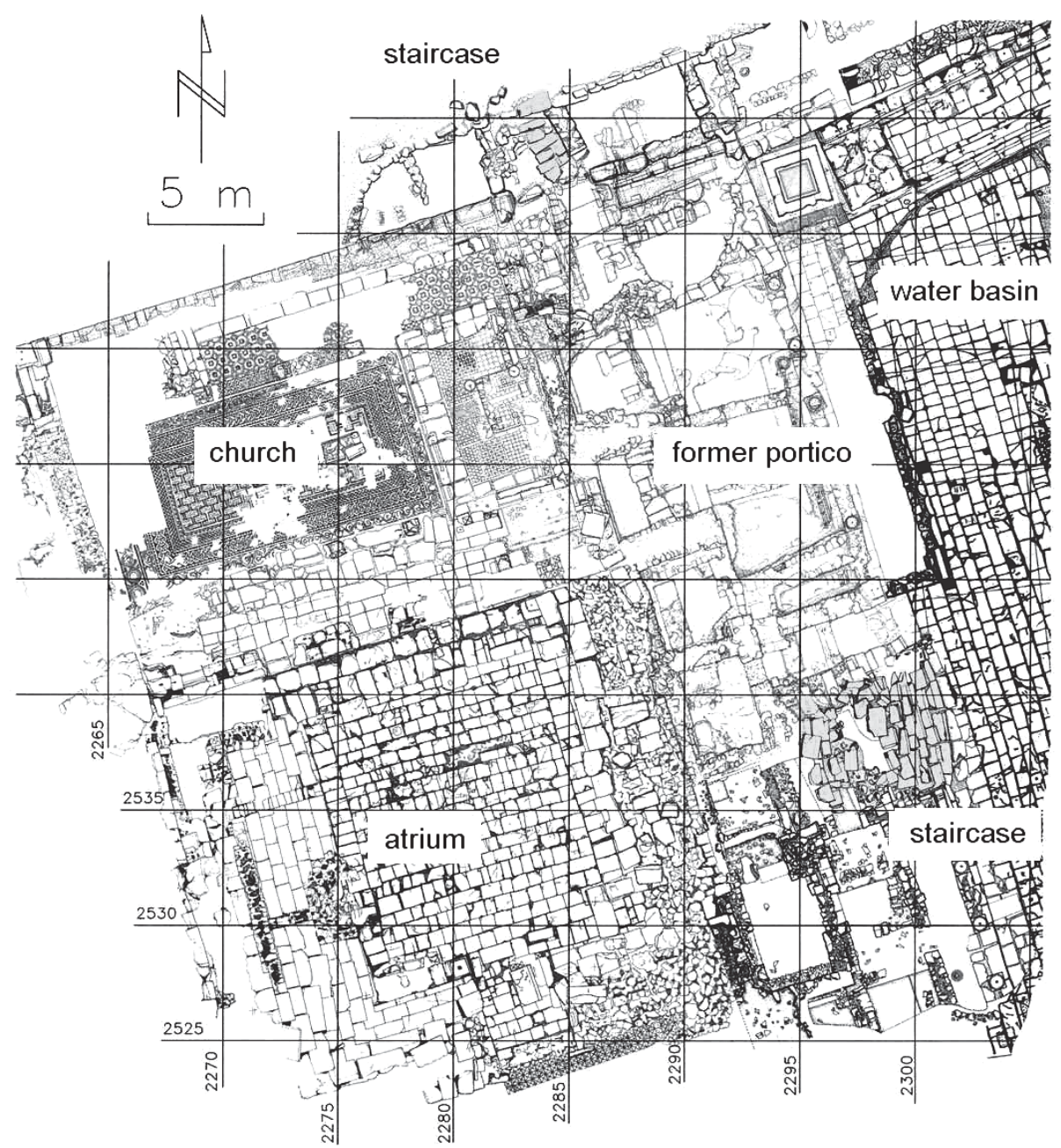

Fig. 6 - The two staircases amidst the encroachment on and around the Upper Agora at Sagalassos. 


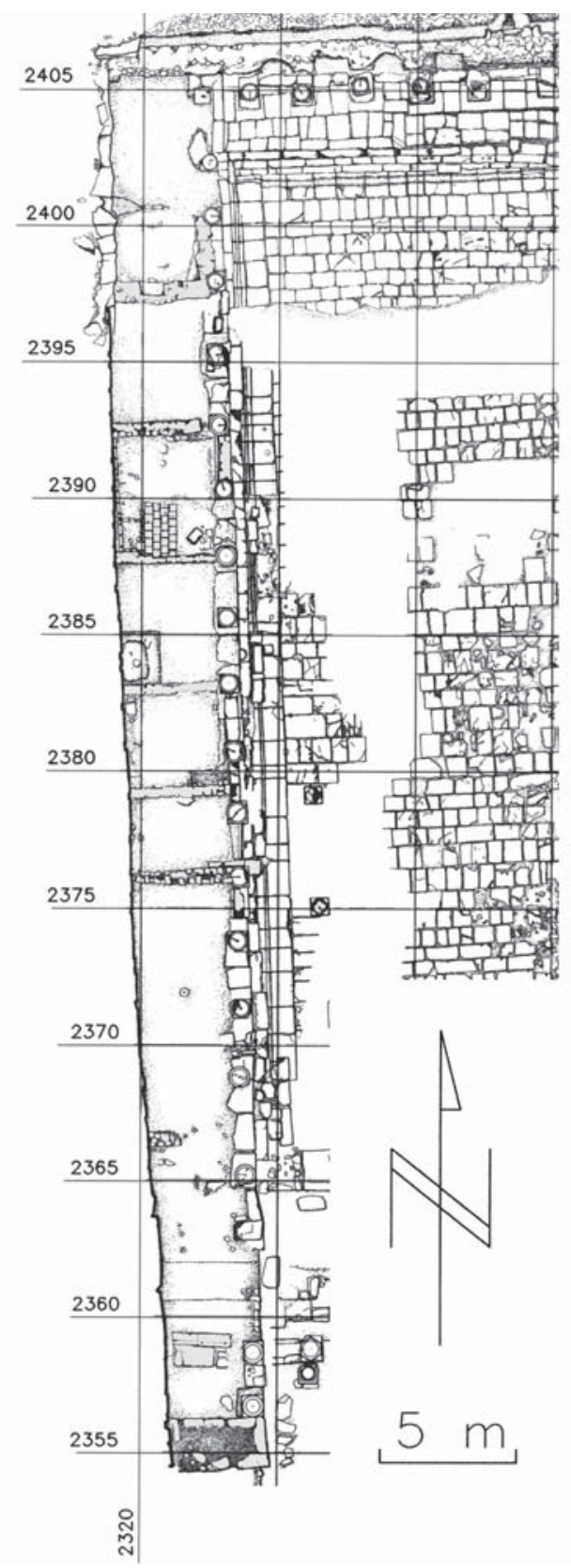

Fig. 7 - Encroachment in the west portico of the Lower Agora at Sagalassos. 


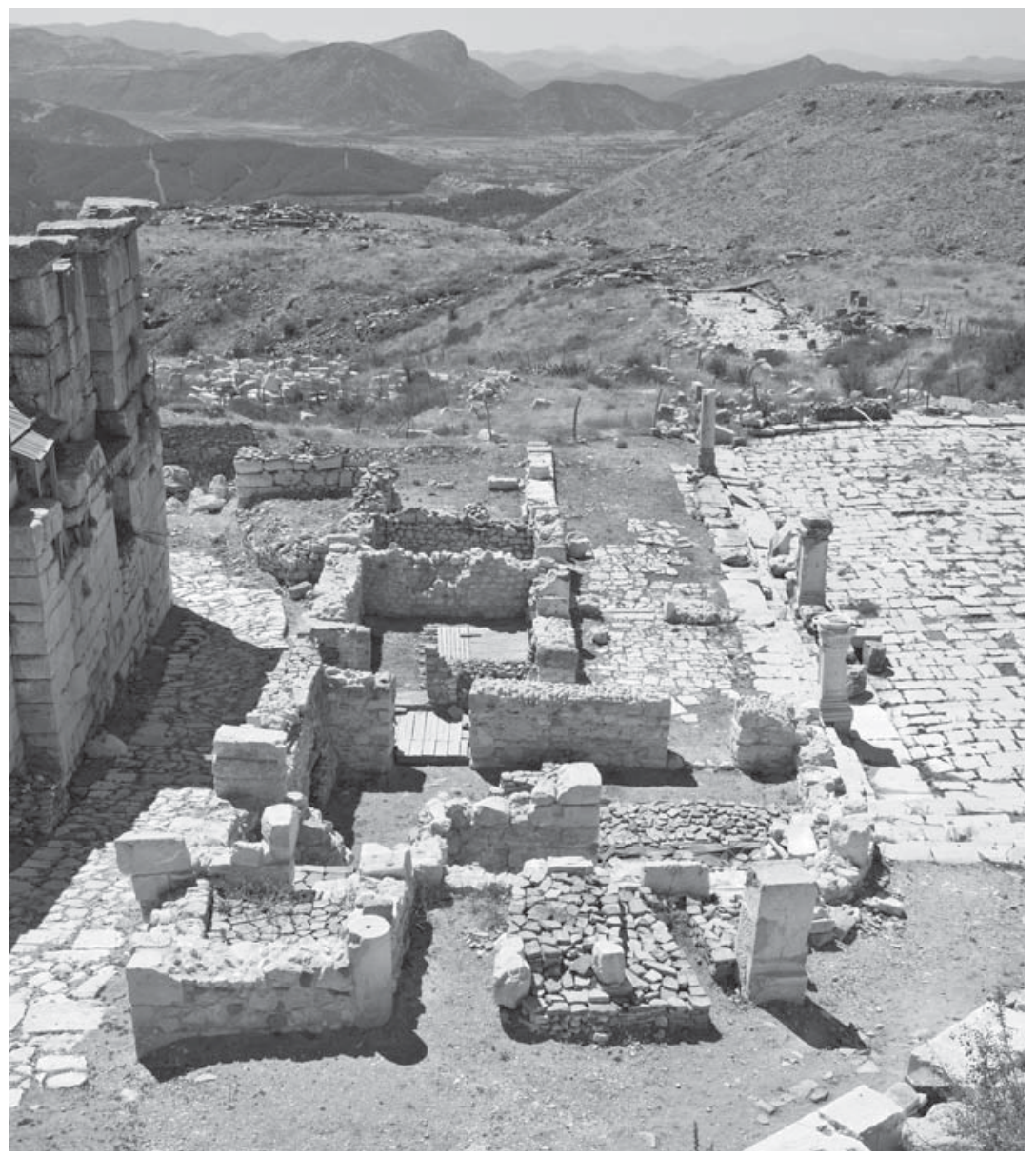

Fig. 8 - The thermopolion installed in the east portico of the Lower Agora at Sagalassos. 


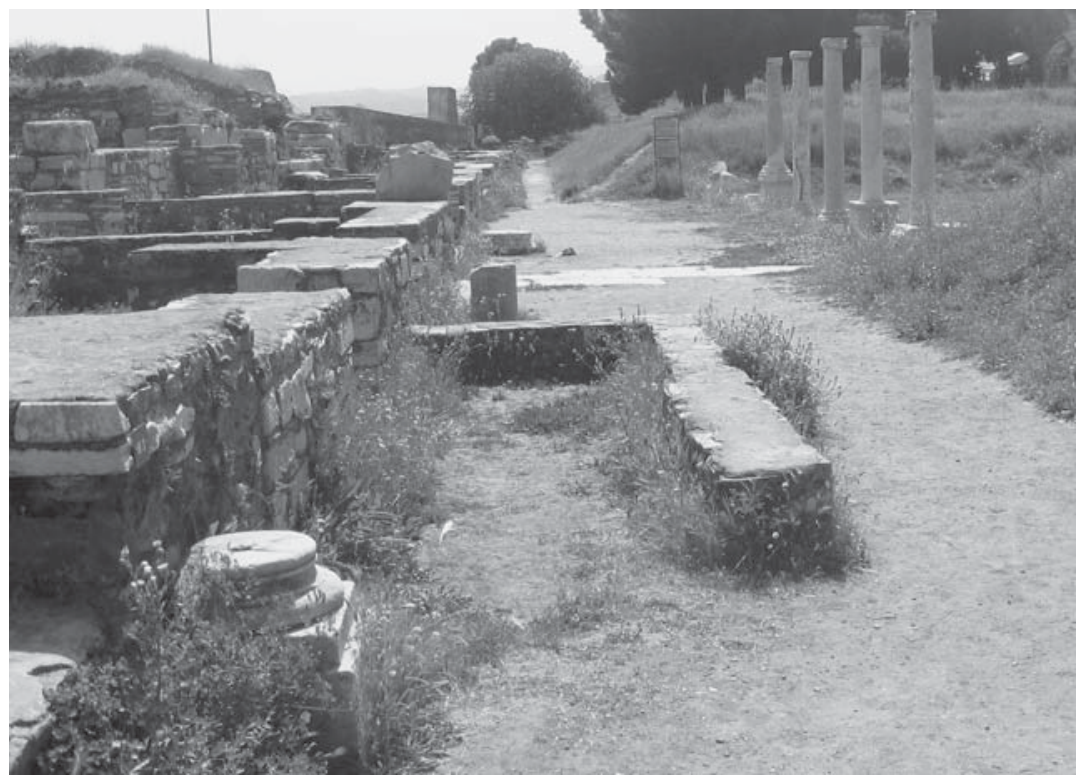

Fig. 9 - Encroachment in the portico of the Marble Road at Sardis.

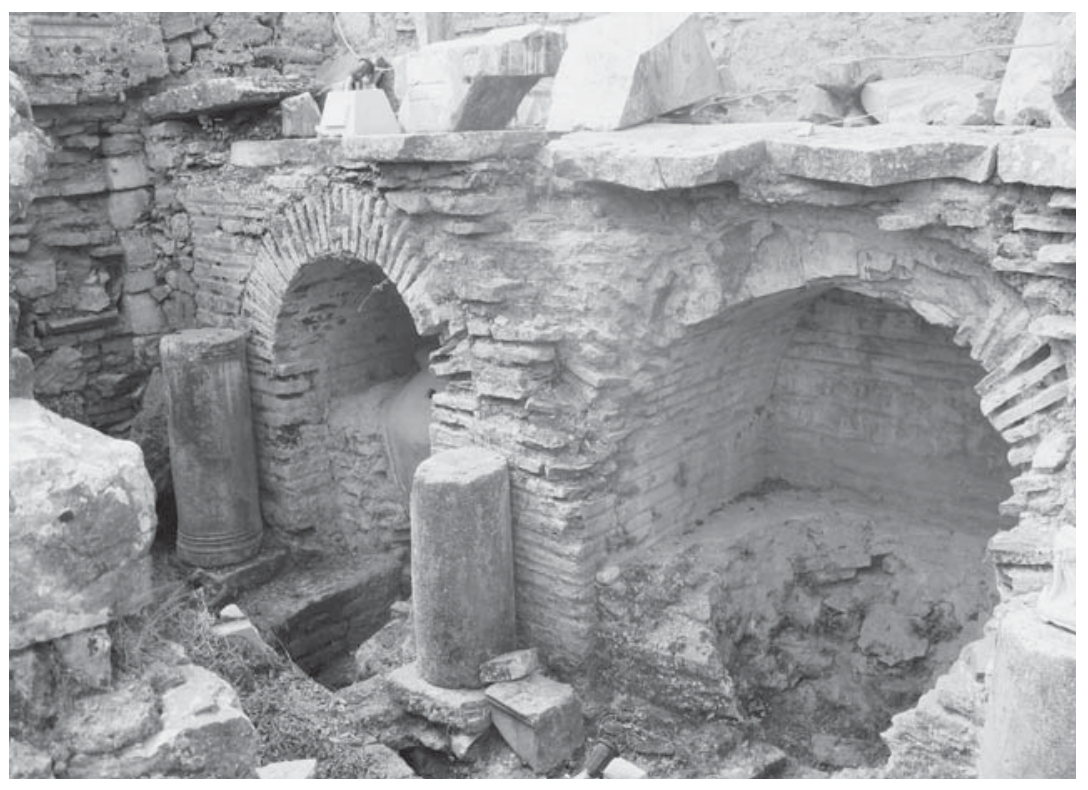

Fig. 10 - Amphorae installed in the so-called Nymphaeum at Ephesus. 


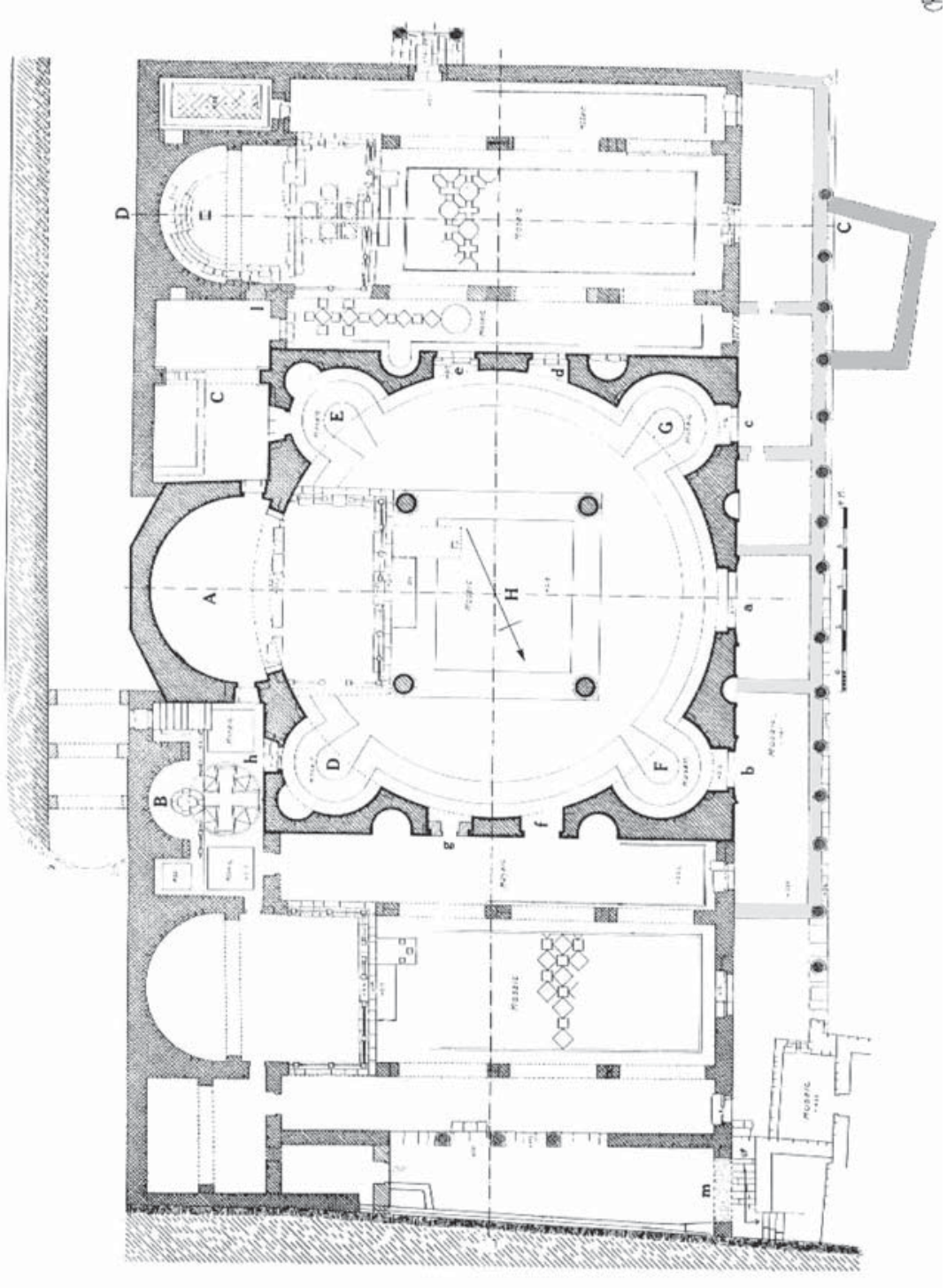

$\approx$ ह

츨

$\stackrel{\infty}{2}$

$\stackrel{\infty}{\Xi}$

.ేี

灵

굴

苂

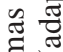

ن

पे

든 한

导

$\approx 0$

낭

苛总

छ

E

点

(

二

$\infty$

江

응

捾

4

它 